Portland State University

PDXScholar

Spring 7-2-2013

\title{
Tokuya Higashigawa's After-Dinner Mysteries: Unusual Detectives in Contemporary Japanese Mystery Fiction
}

Jessica Claire Kindler

Portland State University

Follow this and additional works at: https://pdxscholar.library.pdx.edu/open_access_etds

Part of the Japanese Studies Commons, and the Translation Studies Commons Let us know how access to this document benefits you.

\section{Recommended Citation}

Kindler, Jessica Claire, "Tokuya Higashigawa's After-Dinner Mysteries: Unusual Detectives in Contemporary Japanese Mystery Fiction" (2013). Dissertations and Theses. Paper 1011. https://doi.org/10.15760/etd.1011

This Thesis is brought to you for free and open access. It has been accepted for inclusion in Dissertations and Theses by an authorized administrator of PDXScholar. Please contact us if we can make this document more accessible: pdxscholar@pdx.edu. 
Tokuya Higashigawa’s After-Dinner Mysteries:

Unusual Detectives in Contemporary Japanese Mystery Fiction

\author{
by \\ Jessica Claire Kindler
}

A thesis submitted in partial fulfillment of the requirements for the degree of

\author{
Master of Arts \\ in \\ Japanese
}

\title{
Thesis Committee: \\ Jon Holt, Chair \\ Laurence Kominz \\ Suwako Watanabe
}

Portland State University

2013 
(C) 2013 Jessica Claire Kindler 


\begin{abstract}
The detective fiction (tantei shōsetsu) genre is one that came into Japan from the West around the time of the Meiji Restoration (1868), and soon became wildly popular. Again in recent years, detective fiction has experienced a popularity boom in Japan, and there has been an outpouring of new detective fiction books as well as various television and movie adaptations. It is not a revelation that the Japanese detective fiction genre, while rife with imitation and homage to Western works, took a dramatic turn somewhere along the line, away from celebrated models like Poe, Doyle, and Christie, and developed into a unique subgenre of Japanese prose. However, despite its popularity and innovation, Japanese detective fiction has often been categorized as popular literature (taish $\bar{u}$ bungaku), which is historically disregarded as vulgar and common.

My thesis first consists of a brief introductory history of tantei shōsetsu genre in Japan. This includes a discussion of Japanese writers' anxiety concerning imitation of Western forms and their perception of themselves as imposters and imitators. Following this, I examine the ways in which tantei shōsetsu writers-particularly Edogawa Ranpo (1894 - 1965), the grandfather of the genre in Japan - began to deviate from the Western model in the 1920's. At the same time, I investigate the bias against tantei shōsetsu as a vulgar or even pornographic genre. Through a discussion of literary critic Karatani Kōjin's ideas on the construction of depth in literature, I will demonstrate how Edogawa created, through his deviance from the West, a new kind of construction in detective
\end{abstract}


fiction to bring a different sort of depth to what was generally considered merely a popular and shallow genre.

This discussion includes a look at the ideas of Tsubouchi Shōyō on writing modern novels, and Japanese conceptions of "pure" (junsui) and "popular" (taish $\bar{u})$ literature. Through an examination of several of Edogawa's works and his use of psychology in creating interiority in his characters, I propose that the depth configuration, put forth by Karatani in his critique of canonical modern Japanese literature, is also present in popular fiction, like Edogawa's tantei shōsetsu. When viewed through the lens of Karatani's depth paradigm, we discover how detective fiction and the vulgarity therein may actually have more in common with "pure" fiction created by those writers who followed Shōyō's prescriptions.

In the final section of the introduction, I propose a definition of Japanese detective fiction that links Edogawa's works from the 1920's to the contemporary Japanese detective novel After-Dinner Mysteries (Nazotoki wa dinaa no ato de, 2010), by Higashigawa Tokuya. Thus we see that many of the themes and conventions present in Edogawa remain prevalent in contemporary writing. Finally, I present my translation of the first two chapters of After-Dinner Mysteries. 


\section{Table of Contents}

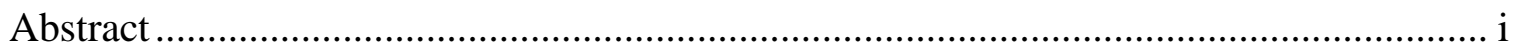

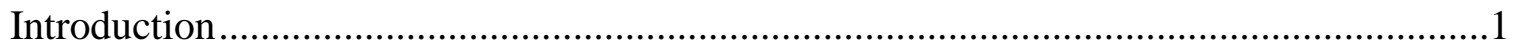

After Dinner Mysteries, Chapter 1

Please Take Your Shoes off at the Crime Scene..........................................................27

After Dinner Mysteries, Chapter 2

Would You Care for a Glass of Poisoned Wine? ..........................................................64

References............................................................. 104 
Introduction:

Psychological Perspective:

The Vulgar and the Creation of Depth in the Detective Fiction of Edogawa Ranpo

"Japan is fifty or one hundred years behind the West, as one can tell from the development of the modern novel," critic Hirabayashi Hatsunosuke wrote in the April 1925 issue of popular magazine New Youth (Shinseinen). "The reason the detective novel hasn't developed in Japan is...that Japanese civilization is scientifically infantile and primitive." "Though harsh, this was a sentiment often repeated by members of the Japanese literary world throughout the late $19^{\text {th }}$ and early $20^{\text {th }}$ century.

However, despite claims concerning the immaturity and poor quality of Japanese literature - as well as a not necessarily unique disparagement of the proliferation of "lowbrow" genres - the detective fiction that Hirabayashi wrote about still enjoyed wild popularity in the 1920's and 30's, and even through the war period, when many writers went underground and the government was enforcing bans on the publishing world. Even today, detective fiction (tantei shōsetsu, or misuterii shōsetsu) is still one of the bestselling genres in Japan. ${ }^{2}$

It is not a revelation that the Japanese tantei shōsetsu genre, while rife with imitation and homage to Western works, took a turn somewhere along the line, away

\footnotetext{
${ }^{1}$ Quoted in Silver, Purloined Letters, 70.

${ }^{2}$ In 2011, Higashigawa Tokuya 's novel After-Dinner Mysteries (Nazotoki wa dinaa no ato de), featured in the following translation, reached a cumulative sales record of 1.81 million copies sold, outstripping Japanese sales for both the Harry Potter series, and Haruki Murakami's popular novel 1Q84. (Based on figures from the yearly Oricon Book Ranking, 2011.)
} 
from celebrated models like Poe, Doyle, and Christie, and became its own unique creation, one that eventually evolved into the modern Japanese detective novel. In this introduction, I will provide a brief history of the detective genre in Japan, focusing on how it arrived from the West and how it was received. Then, I will discuss the ways in which tantei shōsetsu writers - namely Edogawa Ranpo (1894 - 1965), the grandfather of the genre in Japan — began to deviate from the Western model and create an original detective fiction genre for Japan. At the same time, I will present the common conception of popular fiction, including tantei shōsetsu, as low or vulgar writing. Here, I will borrow from literary critic Karatani Kōjin's writings on depth in literature, specifically his definition of depth as a "single-point perspective," which he explains through the metaphor of the "vanishing point" used in painting to create a linear perspective. ${ }^{3}$ In literature, this means a focus on a single perspective or interiority of character, rather than the multi-point perspective that had previously dominated writing. Using this idea, I will examine how Edogawa and his contemporaries created, through their deviance from the West, a new kind of narrative construction in detective fiction that brought a different sort of depth to what was generally considered a shallow genre.

Finally, I will introduce After-Dinner Mysteries (Nazotoki wa dinaa no ato de), and its author Higashigawa Tokuya, and examine the connections between this contemporary work of detective fiction, and the conventions that Edogawa constructed in the earliest years of the genre's popularity in Japan in the 1920s. I hope to show that,

\footnotetext{
${ }^{3}$ Karatani, Origins of Modern Japanese Literature, 143.
} 
using these conventions, Higashigawa also brings depth to the contemporary detective novel.

\section{Tantei Shōsetsu: a brief history}

The advent of the Meiji Restoration in 1868 saw the end of Japan's 200-year seclusion from the rest of the world, and a sudden and dramatic influx of foreign ideas and commodities. This included an enthusiastic consumption of Western art and literature. It was now, for the first time in many years, that Japan was forced to define itself in relation to the rest of the world — to define itself according to what it was not—and found itself lacking. Basil Hall Chamberlain (1850 - 1935), one of the first European Japanologists who was active in the country at the time, wrote of this period that: "educated Japanese have done with their past. They want to be somebody else and something else than what they have been and still partly are."4 This attitude was common in the Westernization of the rest of the world as well, and by turn of the $20^{\text {th }}$ century much of Japan had already internalized the idea that all things Western were more advanced, more mature, and generally better than things non-Western, including things Japanese. This was certainly the case in the world of literature. For example, in his famous Essence of the Novel (Shōsetsu shinzui), Tsubouchi Shōyō (1859 - 1935) makes this comparison of Japanese and Western novel writing:

Comparing the Japanese novel with its Western counterpart is thus like comparing the Utagawa ukiyoe woodblock prints with the Kanō paintings. The prints, though certainly not clumsily executed, lack the quality of refinement; having nothing to offer the viewer's aesthetic sensibilities, they serve merely to amuse women and children. ${ }^{5}$

\footnotetext{
${ }^{4}$ Quoted in Washburn, 4.

5 Tsubouchi, Essence of the Novel, 36.
} 
These were the conditions under which detective fiction was first introduced into Japan. The genre came to Japan, as so many new forms did, in translation, and one of the most prolific translators of the detective novel was sometime newspaper writer and editor Kuroiwa Ruikō (1862-1920). In 1889 alone, Kuroiwa was responsible for twenty-two of the twenty-nine detective novels translated in that year. ${ }^{6}$ The reception of his translations, too, reflected the current trends in literature. The forward to one 1891 translation demonstrates this:

Conventional Japanese novels are all the same... if you read half of one, you know the whole plot. But there comes now onto the Japanese literary scene... something that with its epoch-making originality of conception will set up new standards, stirring into windy maelstrom all our withered leaves, chasing away the conventional, vapid novel: [that something is] the Western novel. ${ }^{7}$

While sensational, this passage echoes the sentiments of many in the Japanese literary world in regards to Western writing, and Kuroiwa suffered from no shortage of readers of his translations. Indeed, many who would go on to be stars of the genre (including Edogawa) first encountered detective fiction through Kuroiwa and his work. ${ }^{8}$ What is interesting about Kuroiwa, and perhaps indicative of things to come for tantei shōsetsu, are the freedoms he took in his translations regarding faithfulness to the original text. At a time when the practice of literary translation recognized few conventions this did not, perhaps, strike Kuroiwa as inappropriate, but some of his

\footnotetext{
${ }^{6}$ Silver, Letters, 59.

${ }^{7}$ Ibid., 59.

${ }^{8}$ Kawana, Murder Most Modern, 23.
} 
practices would certainly raise eyebrows today. ${ }^{9}$ In the preface to his first "translated" work (Hugh Conway's Dark Days, rendered in Japanese as Hōtei no bijin, or The Courtroom Beauty), Kuroiwa openly admits that: "Having read it one time, I took up my brush and freely strung the characters together according to what I retained in my memory, not looking so much as once more at the original after I had begun the manuscript. ${ }^{, 10} \mathrm{He}$ tended to adapt stories as he saw fit—omitting some passages and expanding on others, replacing foreign given- and place-names with more familiar sounding Japanese ones though leaving the stories in their original settings of France or England. ${ }^{11}$ When these works were published, there was also little mention, if any, of the original author. Kuroiwa himself was adamant that he was nothing more than a simple translator, but with so much adaptation, could these truly be called translations? While Kuroiwa seemed to find no inaccuracy in the term, similar borrowings and adaptations would be a major source of frustration for his successors in the tantei shōsetsu genre, especially when they were faced with accusations of imitation.

\section{$\underline{\text { Imitation in Tantei Shōsetsu }}$}

The conception of the West as the pinnacle of modernity was a tricky issue in Japanese literature at the turn of the last century. In order to equal the West, Japanese authors were expected to emulate the Western model, but in doing so were accused of

\footnotetext{
${ }^{9}$ For more on the history of early Japanese translation practices, see Donald Keene's Dawn to the West, especially Chapter 3: The Age of Translation.

${ }^{10}$ Silver, Letters 66.

${ }^{11}$ Ibid., 69.
} 
lacking originality. Yamanouchi Hisaaki describes this contradiction in his introduction to The Search for Authenticity in Modern Japanese Literature:

How could Western culture and their native [Japanese] tradition be harmoniously reconciled to one another when often it [Western culture] persuaded them to hate whatever of their own culture and themselves they had been reared to respect? They felt compelled to imitate and thus be authentic, a contradiction that obviously gnawed at their consciousness. ${ }^{12}$

This sentiment hit home at various levels of the Japanese literary world — not only authors in the popular literature genres, but writers of "pure literature" (junsui bungaku), too, were highly cognizant of the accusations of imitation leveled against them. ${ }^{13}$ In the emerging genre of detective fiction, while Kuroiwa had used the guise of translator to justify what may have otherwise been deemed blatant plagiarism, those who came after him did not have the same luxury.

In 1923, Edogawa Ranpo's first detective story “The Two-Sen Copper Coin” ("Ni-sen dōka") was published in the April issue of New Youth. This was the first piece of purely detective fiction the magazine had published, and it was a great hit, launching Edogawa into a long and successful career. The publication of "Copper Coin" also opened the doors for the continued publication of more Japanese detective fiction in New Youth and magazines like it, which had previously published mainly translated Western works. ${ }^{14}$

${ }^{12}$ Yamanouchi, Modern Japanese Literature, 4.

${ }^{13}$ For example, in the opening chapter of Topographies of Japanese Modernity, Seiji Lippit discusses Akutagawa Ryūnosuke's response to these accusations in his famous essay "Literary, All Too Literary" ("Bungei-teki na, amari bungei-teki na"), as well as his anxiety concerning imitation revealed by his use of doubles, or "doppelgangers" in several of his works (see $62-63$ ).

${ }^{14}$ Silver, 167. 
It should be noted that, while this era saw a dramatic upward swing in the publication of detective fiction by Japanese authors, it was not the first time detective stories had appeared in Japanese literature. Prior to Edogawa's rise to popularity, playwright and author Okamoto Kido $(1872-1939)$ had been releasing a series of detective stories - collectively known as The Casebook of Inspector Hanshichi (Hanshichi torimonochō)—in the magazine Literary Club (Bungei kurabu). However, it was not until about 1923 (the same year as Edogawa's debut) that Okamoto rose to real popularity. ${ }^{15}$

As mentioned previously, Edogawa had been an avid reader of Kuroiwa's translations, as well as having read authors like Poe and Conan Doyle in the original during his time as a student at Waseda University. ${ }^{16}$ What quickly becomes evident in reading Edogawa's work - and even in this very first story —is how aware he is of the borrowing inherent in his writing. In "The Two-Sen Copper Coin," when the character Matsumura is explaining how he cracked a complicated code using a combination of the syllables of the Buddhist chant "naти amida butsu" and Japanese Braille, he tells the narrator, "Were we talking about English or French, of course, all I'd have to do is search for the letter 'e'-like in Poe's story 'The Gold Bug'—but the hitch was the text was in Japanese." ${ }^{17}$ Such tips-of-the-hat are common in Edogawa's writing, and another similar reference is made in Edogawa's The Pomegranate (Zakuro, 1934) when, towards the beginning of the tale, a character is seen reading a copy of Eric C. Bentley's Trent's Last

\footnotetext{
${ }^{15}$ Ibid., 103

${ }^{16}$ Tyler, Modanizumu, 270.

${ }^{17}$ Ibid., 282.
} 
Case (1913), to which Edogawa's mystery is a clear homage. ${ }^{18}$ Regarding this point, Edogawa wrote in his literary diary that he had simply been "showing how I would have handled the trick in [Trent's Last Case] if it had been my own, demonstrating how the work would turn out if it were rewritten in the Japanese style. It was not so much a matter of imitation as it was a matter of saying, 'Have a look at how I would treat the same trick'." 19 In fact, one does not need to look any farther than the penname, Edogawa Ranpo, to find an homage to another writer of detective fiction. Born Hirai Tarō, Edogawa took the name "Edogawa Ranpo" as an homage to one of his favorite authors, Edgar Allen Poe (pronounced Edoga-aren-pō in Japanese).

Along with this more obvious recognition of borrowing, look-alikes and doppelgangers also make numerous appearances in Edogawa's fiction, giving many of these stories an underlying theme of imitation or mimicry. In the story "Beyond the Bizarre" ("Ryoki no hate," 1930) the character Shinagawa, an upright and unexciting personality, is plagued by a look-alike who lives a life of crime and sexual deviance, leading him to question his own hidden drives and desires. ${ }^{20}$ The most telling example, however, is perhaps in "The Twins" ("Sōseiji," 1924). The story features a pair of twins "so strangely identical, so completely the same that it seemed as if [they] had been cast in the same mold." ${ }^{21}$ While one twin is a successful, happily married man, the other twin is "a born rogue," driven to murder by jealousy of his brother's success and marriage to the

\footnotetext{
${ }^{18}$ For a more detailed discussion of these similarities see Silver's introduction to Letters. ${ }^{19}$ Edogawa, quoted in Silver, Letters, 11.

${ }^{20}$ Kawana explores this story in more detail in chapter 2 of Murder (see 62 - 65).

${ }^{21}$ Edogawa, Japanese Tales of Mystery and Imagination, 128.
} 
woman they both loved. ${ }^{22}$ He kills and then impersonates his twin, taking over his brother's life with seemingly complete success. He is only discovered when, after turning to a life of theft when he has squandered all of his brother's money, his fingerprints are identified by the police. "What a fool I had been!" the murderer despairs. "Why, even a grade-school student knows that every person in the world has his own type of fingerprints, and I, of all people, should have known that even twins never have identical fingerprints!" ${ }^{, 23}$ It is not difficult, then, to read into this tale a parable of imitation and its failings - though a pair of "twins" may be identical in every superficial way, it is something inherent in the rogue, the impersonator, which gives him away in the end and reveals him as the lesser of the two, in the same way Japanese writers, Edogawa included, saw themselves as inferior to their Western counterparts. ${ }^{24}$

Another theme found in Edogawa's writing (and that of other tantei shōsetsu authors of the era) was the direct mention of detective fiction within the narrative. It was at times used as a motive for the detective's choice of profession (or the killer's choice of crime). At other times, it was an acknowledgement to readers that they should, indeed, consider what they were reading a work of detective fiction. One might wonder why readers would need to be clued in to such an obvious thing as the genre of the work. It could be that, as detective fiction was a relatively new genre to Japan, authors like

${ }^{22}$ Ibid., 129.

${ }^{23}$ Ibid., 137.

${ }^{24}$ In Silver's introduction to Letters, excerpts from Edogawa's diary reveal how conscious Edogawa was with the imitation found in his work, even driving him at one point to write that he "could no longer write anything that detective story readers would read" (12). 
Edogawa felt it would be prudent to include such hints in their stories. But, as can be discovered in a brief examination, it is also true that stories that fall under the umbrella of tantei shōsetsu do not always meet the expectations readers (and certainly not Western readers) may have of detective fiction.

\section{Movement away from the Western Model}

The first thing new readers to the tantei shōsetsu genre might find unusual is that often in Edogawa (and his contemporaries) the presence of a detective is not necessarily required for a piece of alleged detective fiction at all. Where Western readers may expect the narrative to be from the point of view of the detective himself, or perhaps a Watsonlike sidekick, Edogawa often places his reader in the perpetrator's perspective. This is true of the above-mentioned "Twins," and other famous Edogawa works like "The Psychological Test" (“Shinri shiken," 1925) and "The Human Chair" ("Ningen isu," 1925). It is interesting to note that in all of these stories, the reader sees the perpetrator carrying out his crime, and so already knows all the details of its execution. We find here an interesting twist on the usual pattern that has a detective simultaneously deciphering clues and extrapolating the criminal's moves - instead, what is left to be revealed is not how the crime was committed, but how the villain is caught (or not).

On top of this, when there is a detective involved, he may not even be gainfully employed in the art of detecting — that is to say, in Edogawa this term must take the loose 
definition simply of someone who figures out a mystery. And in the case where the solver of the crime does fall under the classic definition of detective, he is less likely to be someone of pedigree or with actual crime-solving qualifications than he is to be an average Japanese citizen with a knack for detective work. This is very much the case for Edogawa's reoccurring character Akechi Kogorō, who made his first appearance in the 1925 story “The Murder Case on D-Hill” (“D-zaka no satsujin jiken,” 1925). In this first introduction, when the narrator mentions Akechi, he describes him only as "a very strange fellow, with a good head...who enjoyed detective fiction." ${ }^{25}$ While Akechi does eventually develop into a true detective, his beginnings are undeniably humble.

Finally, Edogawa is also known for his trips into the world of "erotic-grotesquenonsense." Usually abbreviated to ero-guro in Japanese, this was the "prewar, bourgeois cultural phenomenon that devoted itself to explorations of the deviant, the bizarre, and the ridiculous." 26 These stories surely skirt the very edge of what Western readers might feel comfortable calling detective fiction. Although most will, at least, involve a murder or two, the focus is taken away from the solving of the crimes and centered much more firmly in the bizarre and grotesque aspects of it. And this is, again, assuming there is a crime at all. In one of Edogawa's famous ero-guro pieces, "The Caterpillar" ("Imomushi," 1929), the story revolves around the wife of an army lieutenant, who has been so injured by war as to have been rendered deaf, mute, and a quadriplegic, having lost both his arms and legs to an artillery shell explosion. While the wife, Tokiko, does commit some violence against her husband before the story ends, the real heart of this weird tale is in

\footnotetext{
${ }^{25}$ Edogawa, Zenshu, 21. Translation mine.

${ }^{26}$ Reichert, "Deviance in Edogawa Ranpo," 2.
} 
the exploration of Tokiko's warring disgust and fascination with her husband's broken body and the power she wields over it. The following passage is just one demonstration of the erotic yet grotesque theme running through the piece:

Suddenly bending over her husband, she smothered his twisted mouth with kisses. Soon a look of deep contentment and pleasure crept into his eyes, followed by an ugly smile. She continued to kiss him-closing her eyes in order to forget his ugliness - and, gradually, she felt a strong urge to tease this poor cripple, who was so utterly helpless... The cripple, kissed with such passion, writhed in the agony of being unable to breath and distorted his face oddly. As always, this sight excited Tokiko strongly. ${ }^{27}$

There is no mystery here except the mystery of Tokiko's psyche, and the twisted relationship she has with her helpless husband. These aspects of eroticism, the grotesque, and psychology are key in an examination of depth in Japanese detective fiction.

\section{$\underline{\text { Karatani and Depth in Literature }}$}

In Japan as in the West-where many of the Japanese conceptions of what makes "modern literature" come from—critics often see depth as the quality which gives a novel merit. In his critical writings on depth in literature, Karatani Kōjin approaches the idea of depth through the metaphor of painting. In literature as in art, he argues, depth is not something humans discovered (that is to say, something that did not exist in art or in thinking before it was represented in these forms), but a construction we learned to use. "The depth we sense in modern literature," he says, "is not something found in reality, perception, or consciousness, but in a single type of perspectival configuration prevalent

${ }^{27}$ Edogawa, Tales of Mystery, 73. 
in this literature." The depth we feel missing in pre-modern literature, he continues, is only a lack of this configuration. ${ }^{28}$

How, then, is depth created? Again, Karatani uses the metaphor of painting "What occurred in the nineteenth century was the transformation of a perspectival configuration emphasizing the horizon (parallel lines extending to an infinitely distant vanishing point) to one that emphasized vertical depth." 29 In art, this "vanishing point" is a mathematical construction, a single point to which the size of all the figures in the painting is relative. In literature, too, a similar construction was created around the idea of interiority: the "vanishing point" of a novel, the single point to which all the threads of the narrative are tied, is the interiority of a single character. Karatani describes this use of the metaphorical vanishing point in the early writings of Mori Ōgai as essential to the author's desire to "make texts transparent":

When [Mori Ōgai] talked about "ideals", it was not in the sense of simply reforming Edo-style literature, as Shōyō had hoped to do, but of a thoroughly reconstituted perspectival configuration, centralized around a vanishing point. In a very strict sense, it was only out of such a perspective that Japanese modern literature could emerge. ${ }^{30}$

However, this was a formula of which Ōgai (and others) would eventually tire, and in an effort to subvert this standard, Karatani says of later Ōgai and the revisions made to his historical writings that: "Whereas the works of Ōgai up to that point had been expressions of meaning, whether 'great' or 'lesser', works after this revised version refuse a concept of transcendental 'meaning'...We are given no glimpse at all into the

\footnotetext{
${ }^{28}$ Karatani, Origins, 137.

${ }^{29}$ Ibid., 143.

${ }^{30}$ Ibid., 150.
} 
'interior"."31 In short, the "single-point perspective" is removed and replaced with something more heterogeneous, a multi-point focus that to modern sensibilities seems flat or shallow.

Early in his essay on depth, Karatani makes the valid point that this depth configuration has since been used by critics as a way to assign value judgments to literature, and demonstrates how flawed such assessments are in light of the construction paradigm, saying: "Modern Japanese literary history has been dominated by the notion that a deepened interiority and its expression are the criteria of literary merit. Literature, however, isn’t even slightly possessed of such a necessity." 32

So, then, is depth problematic for tantei shōsetsu? The answer would seem to lie in its perception as a popular, shallow genre. There are of course issues here concerning the readership of this literature, but looking at the content we see that, at a glance, the detective fiction Edogawa was writing seems to center on the crime itself as much as the characters, taking the reader's attention away from the development of a single character's interiority. I believe, however, that it is in the psychological twist Edogawa adds to his stories, with the reader's gaze frequently directed at the psyche of the criminals, that we find a new point of focus. To discover how this problematizes the depth or lack thereof in Japanese detective fiction, we must take a look at the idea of vulgarity in classical Japanese literature and poetics.

The Common and the Vulgar in Japanese Literature

${ }^{31}$ Ibid., 152.
${ }^{32}$ Ibid., 137. 
When publishers and members of the literary world first began subdividing modern Japanese literature into categories like "popular" (taish $\bar{u})$ and "pure" (junsui), depth was something thought to be found in the modern literary portrayal of the self. This was a self of interiority, one who was "characterized by a set of inner drives, or goals, or desires and aspirations. ${ }^{, 33}$ Authors of the pure literature school strove to create this narrator - one who was often embodied in the "I" of the protagonist. In Essence of the Novel, Shōyō says "A novelist is like a psychologist. His characters must be psychologically convincing. ${ }^{, 34}$ This would seem to be a prescription that, given the above discussion, would suit detective fiction quite well. However, Shōyō qualifies his statement and continues:

I do not mean to imply, even so, that he [the author] should seek out and portray even those deep-buried appetites which embrace obscenity and coarseness. The novel is art. It must avoid lewdness, as music avoids bawdiness; painting, eroticism; and poetry and drama, vulgar language. ${ }^{35}$

Here, a clear line is drawn in Japanese literary history, valorizing pure writing while stigmatizing vulgar writing. With Shōyō's prescriptions for elegant, psychological fiction now setting a precedent, it is not surprising that when popular genres like detective fiction made a debut some forty years later, they would be considered vulgar literature.

In classical Japanese literature, there has been a long-standing juxtaposition of the ideas of "elegance" $(g a)$ and "vulgarity" $(z o k u)$ when determining the worth of any given literature. Important to this distinction is the alternate translation of $z o k u$ as "common". The conflation of these two meanings, vulgar and common, shows the disdain that

${ }^{33}$ Charles Taylor, quoted in Washburn, Dilemma, 9.

${ }^{34}$ Tsubouchi, Essence, 24.

35 Ibid., 28. 
readers in the classical period had for anything that was zoku. This disdain carried through into the modern period among members of the upper class and would still have been present in some form even in Edogawa's day. Accordingly, before the term "popular literature" (taishū bungaku) was coined in the Taishō Period (1912 - 1926), the common man's literature was often referred to as tsüzoku shōsetsu, or "common writings. ${ }^{36}$ For many who subscribed to the idea of pure or elegant literature, works of detective fiction, especially those in the ero-guro category, would not meet the standards of elegant writing. Even with the examinations of psyche found in tantei shōsetsu, was there a psychological—-therefore deep—narrator present in detective fiction? If so, was he still too vulgar to compete for the prestige of a higher class of literature when Edogawa was writing in the 1920's and 30's?

\section{Depth and Vulgar Psychology}

To answer these questions, we can examine Edogawa's "The Human Chair." In this story, the narrator is a carpenter of exceptional skill, but who is "ugly beyond description" and cannot bear to show his face to the outside world. ${ }^{37}$ One day, when crafting a very large, expensive chair, he has the sudden desire to carve out a space inside of it in which he could hide himself and accompany the chair to its destination:

I asked myself if I were not slowly going insane. While in this mental condition, a weird idea suddenly leaped to my mind. Assuredly, it was the whispering of the devil himself. Although it was a sinister idea, I found it attracted me with a powerful magnetism which I found impossible to resist. ${ }^{38}$

\footnotetext{
${ }^{36}$ References are made to this in Washburn, Dilemma (204), and in Tyler, Modanizumu (62).

${ }^{37}$ Edogawa, Tales of Mystery, 4.

${ }^{38}$ Ibid., 8.
} 
Hints of the darker side of the character's mind are already revealing themselves here, as he talks of "weird" and "sinister" ideas. These are also clearly tied to his mental state, as he questions the state of his own sanity. But despite this initial hesitation, he goes through with the plan. After a few days of playing thief in the hotel where the chair is eventually delivered, the tale takes an erotic and grotesque turn when the carpenter starts taking note of the people who come to "sit on his knees", especially the women, until he develops a strange fascination with them and ceases to leave the chair altogether except to make trips to the washroom. ${ }^{39}$ Already deviant in his law-breaking, the chair maker now becomes a voyeur, imagining whole romances centered around the women in his chair. But with his extended time spent contorted in the chair, he becomes practically paralyzed, until he cannot even walk when he is out of the chair, only crawl. "What a madman I was!" he confesses. "Even in the face of all these sufferings I could not persuade myself to abandon my folly and leave that weird world of sensuous pleasure."

In this way, we are given a good view of the protagonist's "interior" as it were, to the point where we are almost taken inside the chair with him as he obsesses over the occupants of his masterpiece. While the inner workings of the chair maker's mind are certainly bizarre, this narrative shows us the "inner drives, or goals" of our protagonist, the very interiority that is demanded of the modern novel, albeit the interiority of an unhealthy mind.

Another example can be found in "The Red Chamber" ("Akai heya," 1925), we are introduced to a secret society that regularly gathers in a red room to "exchange blood-

${ }^{39}$ Ibid., 12.
${ }^{40}$ Ibid., 15. 
curdling horror stories" and we hear the tale of their newest member, Tanaka. ${ }^{41}$ A victim of the ennui common to sudden, large-scale urbanization, ${ }^{42}$ Tanaka dabbles in a number of dangerous pastimes in an attempt to ease his boredom, but he finally strikes on something:

At first I tried to shake [the idea] from me, for indeed my mind was now wading through treacherous swamps, and I knew I would be doomed if I did not check my impulses. And yet, the idea seemed to hold for me a particular fascination which I had never hitherto experienced. In short, gentlemen, the idea was...murder! ${ }^{43}$

He then goes on to detail the cunning ways in which he has brought about the deaths of almost one hundred people, in such a way that no blame would ever be assigned to him. It is a merry amusement, he goes on to say, and the joy each new plot gave him was "akin to that of an artist inspired with a new idea for a painting." ${ }^{44}$ Here we find yet again a focus on the character's mental condition, and the recognition that it is being turned in a dangerous direction. We are able to see Tanaka's interior, and feel the pleasure he takes in his new pastime, while being all the while aware of the horrifying reality that what he is taking such great joy in is the act of murder.

In both of these examples, Edogawa gives us what appears to be a very clear view inside the mind, or the interiority, of the character. And yet—while Edogawa has unarguably become a prominent figure in Japanese literature—tantei shōsetsu is still held to be merely a popular, vulgar genre. I posit that it is this very vulgarity, these depictions

\footnotetext{
41 Ibid., 145.

${ }^{42}$ For more on this, see Kawana, Murder, 39-42.

${ }^{43}$ Edogawa, Tales of Mystery, 148.

${ }^{44}$ Ibid., 157.
} 
of "deep-buried appetites" that inspire the tendency to dismiss the work of Japanese detective fiction writers as mere "popular literature." $" 45$ The psychology that Edogawa and his contemporaries chose to examine in their characters was one that appealed to these "deep-buried" desires of the readers, desires that proponents of pure literature would have seen as "obscen[e] and coarse[]." But it is in utilizing psychology in this way, "becoming a psychologist" as Shōyō dictated, that Edogawa uses the vulgarity of his material to create a new kind of depth. He finds his interiority and depth in the psychology of his characters but in a way Shōyō would have abhorred, perhaps even found pornographic. ${ }^{46}$ Edogawa finds his depth in the vulgar and weird, in the twisted, scary aspects of the human psyche.

\section{Defining Tantei Shōsetsu}

How then can one define Japanese detective fiction? How different is it, really, from its Western counterpart? It is worth mentioning here that, while the Japanese word tantei literally translates to "detective" (meaning the occupation), Edogawa's use of the term in early discussions of the genre tends to be fairly fluid, giving it the almost adjectival quality found in the English -ive ending. In Edogawa's 1926 essay, "Is Detective Fiction Popular Literature?” ("Tantei shōsetsu wa taishū bungei ka") he explores the "detective-ness" involved in such pursuits as academic research and diplomacy, using the words tantei and tantei-teki ("detective-like") both for description

\footnotetext{
${ }^{45}$ Edogawa, "Is Detective Fiction Popular Literature?" ( "Tantei shōsetsu wa taishū bungei ka"), in Hitori no bashō no mondai, 204.

${ }^{46}$ From Shōyō, Essence: "The only really popular stories are those which are sadistic or pornographic. Very few people even so much as glance at more serious offerings" (2).
} 
purposes, though the first is grammatically speaking a noun. With this in mind, it is not so surprising that the Japanese genre tends to encompass a wide variety of things that have even a hint of "detective-ness", regardless of the presence—or ability—of an actual detective. After the war, the genre came to be commonly classified as "deductive" (suiri) fiction, or simply as "mystery" (misuteri) fiction, opening the doors for a broader category of crime fiction.

However, looking at Edogawa's work, as well as more modern detective fiction, we can see a number of patterns and conventions that reoccur:

1) As demonstrated in the above examination of Edogawa's use of psychology in his stories, there is a tendency to focus on how or why a crime was committed rather than who committed it. So, to borrow a term from Kawana, instead of the whodunit, Japanese detective fiction is more concerned with the howdunit and the whydunit.

2) When a detective is present in the story, he is often someone other than the main character, removed from the opportunity to narrate the story. This is true of Edogawa's Akechi-who often shows up only to solve the mystery, as a friend or acquaintance of one of the other characters - and, as we will see, of the real "detective" in Higashigawa's After-Dinner Mysteries.

3) Finally, when Japanese detective fiction features a detective at all, he will very often be someone with no officially recognized credentials as such. Akechi, again, is one of these "everyman" detectives: just a strange fellow with a knack for solving crimes. And in contemporary Japanese detective fiction, too, 
this "everyman detective" is a ubiquitous presence-we see him again in Kageyama, the unlikely detective in After-Dinner Mysteries, as well.

\section{$\underline{\text { After-Dinner Mysteries }}$}

During the 2012 spring Japanese TV drama season, detective fiction and the tantei genre experienced a boom in popularity. The dramatized version of Nazotoki wa dinaa no ato de, having completed a successful run in the winter drama season, premiered a two hour special in spring to usher in two new detective series based on detective fiction novels: The Deductions of Holmes, the Calico Cat (Mikeneko Hōmusu no suiri) by Akagawa Jirō and The Locked Room (Kagi no kakatta heya) by Kishi Yūsuke. ${ }^{47}$ In all of these works we find the aforementioned "everyman detective". Though this character is certainly not the only trope used in Japanese detective stories, he appears in all of these series: in Holmes we have a policeman who hates his job but solves crimes with the help of a mysterious talking cat; in The Locked Room, a security company employee with a knack for lock-picking. And then, in After-Dinner Mysteries, we find another amateur detective in an unexpected place.

After-Dinner Mysteries is a series of short stories about the misadventures of Hōshō Reiko, the only female detective at the Kunitachi City Police Department. Her boss, Inspector Kazamatsuri, is an over-the-top and rather useless caricature of a policeman. Reiko has very little patience for his antics, but has to maintain a modicum of respect in order to keep her secret: in truth, Reiko is the heiress to the internationally known Hōshō Group, and goes home at night to a palatial mansion managed by her own

${ }^{47}$ Information taken from Fuji Television's Upcoming Drama schedule for March 2012. 
personal butler. But this heiress-turned-cop is not, in fact, our unlikely detective. The other half of Reiko's secret is that she does not actually solve any of the crimes: her butler, Kageyama, does.

Here again we encounter an "odd fellow" with a knack for detective work, similar to Edogawa's Akechi. In Kageyama's case, he is odd not for having an eccentric hobby, but for his manner. Most of the time he is the perfect model of all a butler should be: in more than one instance, Higashigawa uses the phrase shitsuji-rashii ("butler-like") to describe Kageyama, a phrase that implies not just likeness, but something more like an ideal. However, despite his exemplary butler-like behavior, when Reiko is too slow to figure out a case Kageyama is able — through a unique use of keigo, Japanese polite-style language - to insult her viciously while still maintaining proper butler-like speech and at the same time unraveling the mystery. Another similarity that After-Dinner Mysteries has with classic Japanese detective fiction is that most of the stories in the series do not focus around identifying the killer but on the logistics and motive of the crime. In the very first story ("Please Take off Your Shoes at the Crime Scene"), Higashigawa spends nearly ten pages having Kageyama explain the finer points of how the crime took place, and the story ends without the killer ever being properly identified or apprehended. Again, in story number two, the last quarter of the story is devoted to the revelation of the killer's methods, but the killer himself is revealed by Kageyama with "surprising ease" (assari to) in a single throw-away line. ${ }^{48}$

${ }^{48}$ Higashigawa, 79. All of the following translations are mine unless otherwise stated. 
Though their focus on the howdunit is similar, the mysteries in After-Dinner Mysteries are certainly a different breed than Edogawa's ero-guro thrillers. Compared to the murderous twins and casual mass-murders in Edogawa, the strangling and poisoning that goes on in After-Dinner Mysteries seems almost tame. Even so, these works still have a similar approach to bringing depth to their work: both Edogawa and Higashigawa make a psychological exploration of the minds of their characters. However, where Edogawa was exploring the psyches of his killers, Higashigawa turns the readers' attention to the psyche of his would-be detective, Reiko. We see Reiko struggle to unlock her various cases, as well as struggle to discover her own identity: detective, or pampered heiress, or something in between?

Throughout the stories in After-Dinner Mysteries, we see the crimes unravel from Reiko's point of view, though not directly in the first-person as often happens in Edogawa. Many of the lines in Higashigawa's narrative can also be read as Reiko's own thoughts, though the conventions of Japanese fiction writing do not always demand a clarifying dialogue- or thought-tag. This phenomenon crops up early in the first story of the collection, when Reiko is investigating a crime scene with Inspector Kazamatsuri. The narrative moves back and forth between an objective third-person, and something that sounds much more like a subjective first-person. In one line, the narration seems to interrupt itself halfway through when we see: "Just as Reiko was starting to get the situation organized in her head, beside her Inspector Kazamatsuri started running his tra-no, that is, he offered some valuable suggestions. ${ }^{, 49}$ In the Japanese here we see iya,

${ }^{49}$ Ibid., 9. 
a very conversational "no", which changes the tone of the narrative to one that sounds more personal.

Through scenes like this one, Reiko also provides an interesting voice for the juxtaposition of her two detective companions, Inspector Kazamatsuri and the butler Kageyama. Though Kazamatsuri is a detective in name, through Reiko's observations we see his true incompetence as he fumbles through each case. At the same time, Reiko's viewpoint also provides a look at the true detective skill possessed by the "everyman" Kageyama, who need only hear Reiko describe a case once to be able to discover the how- and whodunit. We experience, too, her frustration with both of these characters. In the case of Inspector Kazamatsuri, Reiko always has a "hard time" dealing with him (nigate in the Japanese) and his tendency to quickly jump to conclusions in their investigations, and also has to put up with his casual flirtations and "sexual harassment." ${ }^{, 50}$ On the other hand, Reiko's frustration with Kageyama stems from being called an idiot by her own butler when she is unable to figure out a case, but also from the ease with which he can solve the mysteries that bewilder her. In the contrast between Kazamatsuri and Kageyama, we can see again the conflict Reiko finds within herself. As in classic detective fiction, there is a sense of anxiety at the doubling that occurs when Reiko must consider whether she is only a caricature or a competent detective.

In the afterword to the pocket edition of After-Dinner Mysteries, critic Sengai Akiyuki expands upon the particular trait Kageyama possesses of being able to solve a crime without having ever set foot on the crime scene. This ability, he says, is a common

${ }^{50}$ Ibid., 22. 
trait in Higashigawa's characters and a reoccurring trope in detective fiction: the armchair detective (anraku-isu tantei). He is not a detective who necessarily solves all his mysteries literally from an armchair, but rather one who does so in the same way Kageyama solves mysteries, that is, from a distance. The armchair detective receives the details of the case from another person, usually someone working in an official capacity, but is able to deduce critical information that no one else was able to perceive, and thereby solve the crime without ever seeing the crime scene or meeting anyone connected with the crime.$^{51}$ It is this, perhaps, that is part of the reason behind the popularity of After-Dinner Mysteries, and other such armchair (or everyman) detective stories. As the details of the case are laid out for Kageyama, so are they laid out for the reader, and the reader is given a chance to make the same deductions as Kageyama, and perhaps solve a crime that even the police cannot.

So now I invite my readers to do the same in the following translation of the first two stories of After-Dinner Mysteries: "Please Take Your Shoes off at the Crime Scene" and "Would You Care for a Glass of Poisoned Wine?" Each story, and each case therein, presents a unique mystery that is difficult to solve — but not impossible, if one is able to analyze the clues correctly. Additionally, both mysteries hinge on something closely linked to Japanese culture that is key to the unraveling of the mystery. In the first, we see a corpse who is wearing shoes inside the house—-something a Japanese person would normally never do-and in the second, a glass of wine left as a "midnight snack" or sashiire: a refreshment left as a gift or to thank someone. With these particularly

${ }^{51}$ Sengai, "Kaisetsu" in Higashigawa, 342. 
Japanese twists, and through the traditions of Japanese detective fiction that carry through from Edogawa to this contemporary work, Higashigawa creates a truly unique piece of contemporary Japanese detective fiction. 
After Dinner Mysteries

by Tokuya Higashigawa

\section{Chapter 1: Please Take Your Shoes off at the Crime Scene}

A one-room apartment. Reiko Hōshō rang the bell. The door opened a crack, only as much as the length of the chain would allow, and a man peered out. From his place beside Reiko, Inspector Kazamatsuri whipped out his notebook. Suddenly, the man on the other side of the door-Yuuya Tashiro_-went pale. It seemed he had not been expecting their visit, and apparently it was not a welcome intrusion. Well, there's nothing we can do about that, Reiko thought. There weren't many people who would be expecting a visit from the police, and even fewer who would welcome them with open arms.

"Is there something I can do for you, detective?"

"As a matter of fact," Inspector Kazamatsuri said self-importantly, "we'd like to ask you a few things about a woman named Hitomi Yoshimoto.”

"Wh—-hold on, detective. Why are you asking me about this? Did she do something?"

“Oh, it seems you haven't heard, then?” Inspector Kazamatsuri made room for a dramatic pause, watching Tashiro's reaction, before he finally spoke. "Hitomi Yoshimoto was murdered last night."

"What?!" With a look of astonishment, Tashiro removed the chain-lock, put on his shoes, and stepped out of the door. "I see. In that case, why don't we go talk somewhere else." 
Yuuya Tashiro did not invite the detectives into his house, or even let them set a foot inside, before quickly shutting the door.

But just as the door closed, Reiko saw it. In the messy line of sneakers and loafers by the door, in a corner, was a lonely pair of white high-heels. So that was why he didn't want to let them in. He already had a new girlfriend. And, suddenly, an image of yesterday’s crime scene floated through Reiko's mind.

Hitomi Yoshimoto had not been wearing heels, but boots.

In Kunitachi City, if one saw a metallic-silver Jaguar in the neighborhood of a crime scene, there was no mistake: it had to be Inspector Kazamatsuri. Silver Jaguars were not something one saw in Kunitachi every day, and they were an even rarer find at crime scenes.

It was Saturday, October 15th, 7:30pm. At the south exit of Kunitachi Station, University Street — the heart of this stylish, traditional town — was bustling with students and office workers. On the other side of the station at the north exit, just a few minutes' walk brought you to a homey residential area. Here, the north end of the second district was bustling with people in police uniforms.

It looked like Inspector Kazamatsuri had already arrived at the three-story apartment building. As she stepped out of a patrol car, Reiko glanced sidelong at the silhouette of the parked Jaguar, then ducked under the yellow police tape. She climbed the metal stairs on the outside of the building, and came to apartment 304 . Nodding to the officer standing by the door, she stepped into the crime scene: an exceedingly plain oneroom apartment, perfect for someone living alone. There was a small space for taking off 
shoes just in front of the door, and beyond that stretched a narrow, carpeted hallway. Inspector Kazamatsuri was standing in the hallway, dressed in a three-piece British suit.

"Hey, you finally got here. I was worried you got lost somewhere, Miss Hōshō." „52

"I'm very sorry for being late," Reiko bowed her head meekly, but there was one point she could not let slide. "Um - Inspector, I wonder if you could not call me 'Miss'? Other people might pick it up, so...”

"Oh, you think?" Inspector Kazamatsuri cocked his head to the side as if to say What's wrong with that?

Inspector Kazamatsuri would be thirty-two this year, and was still single. But he was not your average bachelor. His father was the president of Kazamatsuri Motors, a mid-size auto maker, and that made the Inspector the heir to a fortune. His nickname, "Lord Bachelor," certainly fit. But despite all this, the position he held at the Kunitachi Police Department was merely "Inspector."

This was something hard for just anyone to understand. If you asked him why he was only an inspector, he always gave the same calm smile and said: "Really, I wanted to be a pro baseball player." Which wasn't really an answer at all, but it wasn't necessarily a joke, either. In fact, rumor had it that his name had been fairly well known in the high school baseball circuit. To sum up the existence of Inspector Kazamatsuri in a simple metaphor, something like this might be fitting: when Mitsuro Hanagata, heir to the Hanagata Motors fortune, failed to get into the Hanshin Tigers, there was nothing left but to join the police force, since he had already passed the police academy exam. (And

52 お婹さ 
yes - that's a reference to the Star of the Giants manga.) Or, more simply: "A rich young playboy became a policeman." That version would definitely piss off the man in question, though.

Reiko Hōshō always had a hard time with the inspector. And it seemed Inspector Kazamatsuri hadn't noticed, even in the slightest. It was amazing that someone with such bad instincts had even become an inspector at all.

"Our victim was the occupant of this apartment: Hitomi Yoshimoto, 25, temp worker. Take a look."

Inspector Kazamatsuri pointed to a door at the end of the narrow hallway. Reiko opened the door, and stepped timidly onto the scene. Inside was a room with a hardwood floor, about 10 meters square.

The body was just inside the door, lying face down and spread-eagle on the floor. Fortunately, there was no blood. It looked like she had been strangled somehow. Reiko had been prepared for a grisly, blood-spattered scene; she laid a hand on her chest and let out a relieved sigh. At the same time, Reiko had a strange feeling about the body. It was something about what the victim was wearing: a denim skirt, and a checkered shirt; on her back, she had a little backpack. She was clearly dressed for going out. On top of that, she was even wearing shoes. Brown boots, to be exact. Boots, in the house. That was strange.

Just as Reiko was starting to get the situation organized in her head, beside her Inspector Kazamatsuri started running his tra —no, that is, he offered some valuable suggestions. 
“So, let's say our victim was attacked by someone just as she was getting home. She resisted fiercely, but was eventually overcome and strangled by her attacker in this room. That's the kind of story that comes to mind. But that's not it. Look around, Hōshō, look at the hallway that leads from the door to this room. You can't see a single thing that looks like a footprint. The hardwood in this room, too, is spotless. Even though the victim was wearing shoes! Don't you think that's a bit strange?”

You don't have to tell me, I noticed something strange the moment I saw the crime scene. Reiko thought about just saying it straight out, but she got the feeling that would ruin her boss' mood, so she decided it would be more appropriate to act impressed.

"Just as you say, Inspector, it is strange. I wonder what could have happened?" It might have been that the victim was killed somewhere else, and only brought into this room after she was dead. If the killer had carried the body, then that would explain why the victim hadn't left any footprints in the hallway or on the hardwood in here, Reiko thought. But just as soon as she had the thought, Inspector Kazamatsuri was off again.

“Or perhaps, the perp killed the victim somewhere else, then carried the body into this room. If he carried the body, of course there wouldn't have been any footprints." Which was the exact same thing Reiko had already thought. Somehow, she felt like she was becoming a victim of copyright infringement. But, well, whatever. The point was, if this reasoning was sound, it instantly cut the pool of suspects in half. That is, it had to be a man, since lifting a body would probably be difficult for a woman alone. Reiko had just gotten that far when Inspector Kazamatsuri jumped in yet again. 
"Yes, the killer must be a man! It would be impossible for a woman to lift the body. And, if it was a one-on-one fight, her attacker probably couldn't have strangled her with such a small difference in strength. The killer must be a man after all."

“I see. Brilliant, Inspector.” Inspector Kazamatsuri was certainly a pro when it came to being the first to say things everyone was already thinking. But Reiko couldn't just stand here and keep acting impressed. "Inspector, do you think we can assume this was done by one man with no accomplices? For example, if it was two women, couldn't they have easily shared the work of strangling and carrying the victim?"

"You don't have to tell me, I noticed that possibility as soon as I saw the crime scene."

Lies! He only thought of it after I said it, right? Such a man-always has to come out on top!

"Is something wrong, Hōshō?"

"No, Inspector, a brilliant deduction as always."

That was all Reiko could bring herself to say. She really did have a hard time dealing with Inspector Kazamatsuri.

Soon, the forensics exam was complete and a number of important things came to light. First, the time of death was determined to be around 6pm. The cause of death, as expected, was suffocation by strangling. No other wounds or traces of assault were found. The forensics team had guessed the weapon was some kind of thin rope.

Waiting for the body to be brought out, Reiko examined the victim's room once again. She didn't want to insult the deceased girl, but with such a messy apartment, it 
was hard to see a sign that she had ever been tidy or organized. Books overflowed from the bookshelf, CDs spilled out of the CD rack, and a month's worth of newspapers was stuffed into the newspaper bin. The bed sheets still looked like someone had just crawled out of them. Well, this is pretty typical for a young girl living alone, and was not at all surprising.

Still thinking of victim's messy room, Reiko went and opened the only window. Outside was a small veranda, about a meter square. A laundry line had been hung there, and a number of miscellaneous clothing items were hung out to dry: shirts, jeans, under things, even a pair of running shoes.

But Inspector Kazamatsuri seemed more interested in the laundry line itself than the clothes hung on it, and started examining it carefully.

“The murder weapon was a thin rope," Inspector Kazamatsuri whispered, and Reiko had an unpleasant suspicion.

“Surely, Inspector, you weren't about to suggest that the killer strangled the victim, then took the rope out to the veranda and hung the laundry on it?" "No, of course not."

No, it was perfectly clear that those were the exact thought that had been running through his head. Reiko could tell. "Perhaps the perpetrator took the rope with him. It's not such a bulky thing to carry, probably."

"That's right," the Inspector continued, turning his back on the laundry line and heading back into the hardwood room. "Well, it's about time we question the person who discovered the crime scene." 
The woman who had discovered the scene was called right away. Her name was Eri Sugimura, an office worker who lived in room 301 of the apartment building. She had found Hitomi Yoshimoto's body around 7pm. According to her testimony, Sugimura had been going over to invite Yoshimoto out for drinks, as she usually did, and had realized something was wrong.

"Her door was unlocked. She was much more careful than other people about making sure the door was locked, and would never have forgotten to do it. I thought maybe Hitomi was inside, so I opened the door and called for her, but she didn't answer. The lights were off, and it didn't seem like anyone was there. But when I looked closely, I saw that the door at the end of the hallway was open, and someone had fallen down on the floor. I was surprised, and ran to the room and-and when I turned the lights on, it was Hitomi."

Shocked by the death of her friend, Sugimura had used her cell phone to call 911 and report the incident right away. It was a hard and fast rule of police investigation to suspect the person who had discovered the crime scene, but there was nothing suspicious about Eri Sugimura's story. If what she said was true, that meant the scene had been discovered barely an hour after the crime was committed. If Sugimura hadn't visited her friend, the incident would probably not have been detected until at least the next day.

After finishing up their questioning with Eri Sugimura, Reiko and the Inspector left room 304 for the time being to question people living in the neighborhood. Perhaps because the crime had been discovered so early, they were able to take a number of important testimonies. First, there was Kensaku Kawahara, the middle-aged landlord of 
the building who himself lived on the first floor. "I saw the victim while she was still alive," he told the detectives.

"It was when I went to get the evening paper from the mailbox. All the mailboxes for this building are grouped together by the stairs on the first floor, and that's where I passed Ms. Yoshimoto on her way home. She was walking alone from the direction of the train station when she passed me. Yeah, that's right. She was wearing a denim miniskirt and brown boots."

“About what time was that?" Inspector Kazamatsuri asked, making a show of looking at his favorite Rolex.

“It was a little bit after my 5 o'clock TV show had ended, so I guess it was around 6pm."

The time of death had been around 6pm. The excitement in Inspector Kazamatsuri's voice rose.

"And how did Ms. Yoshimoto seem at the time? Did you speak with her at all?" "Yes, I said 'Welcome back', but she looked kind of troubled and just said 'yeah,' or something vague like that before running up the stairs. ${ }^{53}$ Now that I think about it, she did seem a bit odd. She's usually a bit more civil, and always greets me politely, since I'm her landlord."

"After you crossed paths, what did you do?"

53 "Welcome back": for the Japanese ritual expression okaerinasai, said when someone has returned home. Usually, Hitomi Yoshimoto would have replied with tadaima ("I'm back"), the accompanying expression. 
"Well, of course I went right back to my room. I'm not lying-if you don't trust me, just ask the owner of the fruit-stand across the street. He was outside the shop right when she went by."

The two detectives went immediately to the fruit-stand across from the apartment. "Mr. Kawahara did cross paths with a young woman by the mailboxes," the owner testified, and then further confirmed that Mr. Kawahara had gone right back to his apartment. But it wasn't like the fruit-stand owner stood around watching the apartment complex twenty-four hours a day. That was all he could tell them.

The next piece of important information the detectives received was from Yasuo Moritani, a college student living on the second floor of the apartment building. "I heard footsteps that might have been the killer," he testified.

"As you can see, my room, 201, is right next to the stairs. So I can hear people going up and down all the time. And it's a metal staircase, so it echoes a lot, too. The footsteps I heard were especially noisy. Like someone running down the stairs, bam-bambam, you know? Yeah, not going up, but footsteps going down. Definitely. I didn't really think anything of it at the time, but there was a murder on the third floor, right? I just thought, maybe that was the sound of the killer running away or something. What time was it? I think it was right around 6pm.”

This, too, agreed with the estimated time of the crime.

"Did you hear any other footsteps?"

“Well, I might've heard some, but I don't really remember. It's just that I happened to remember that I heard footsteps around 6pm." 
In the end, it seemed Moritani didn't have any particular recollection of hearing any other footsteps.

Once the two detectives finished their questioning, they headed up the stairs and back to the third floor crime scene.

"Inspector," Reiko asked as they climbed the stairs. "Should we assume the footsteps Moritani heard were the sound of the killer fleeing the scene?"

“No, it's still too soon to say, Hōshō. Could've just been some noisy person who had nothing to do with the crime, who just happened to be going down the stairs at the same time."

If that was so, it made for a fairly misleading story, but those kinds of things happened in real life.

“But then, Inspector, Kawahara's testimony is certainly important, isn't it? Hitomi Yoshimoto passed Kawahara by the mailboxes when she was coming home. She was alive up until then. So she must have been murdered immediately afterwards. That means that, after coming up these stairs to the third floor, going down the hallway, arriving at room 304, she was killed at some point in the tiny space of time when she had stopped inside the door to take off her shoes. Then, the killer carried the body into the other room. That's what must have happened, right, Inspector?"

This was the only natural conclusion she could come to, assuming the victim had still had her boots on when she died. However, Inspector Kazamatsuri didn't seem to think much of her deduction. 
“Hmm, I wonder, Hōshō, I wonder.” He gave a little laugh through his nose, then, as if he were trying to channel Shigeru Amachi, ${ }^{54}$ he furrowed his brows deeply and made a deduction of his own.

"What if the killer murdered Yoshimoto in the hardwood room, then put her boots back on, hoping to confuse us - to make it look like he did it before she got to the room-how about that? I think it could be a real possibility."

“No, I don't think that's it, Inspector," Reiko countered immediately. "Putting boots on a dead body is much easier said than done. Not to mention, the boots the victim was wearing were the kind you have to lace up. Those are hard to put on even when you're doing it yourself. How much harder would it be to put them on a dead body, then? I just don't think it's possible that the killer went to that much trouble."

"Well of course, that's exactly what I was thinking," Inspector Kazamatsuri said, retreating right away. "It' $d$ be ridiculous to put boots on a dead body. If they had, the body would probably show signs of it that would have come up during forensics. Yeah, it's unlikely the boots were put back on after she was dead. Impossible, even. Right, Hōshō?"

“...Yes, just as you say, Inspector."

Hadn't there been someone, not one minute ago, with that deep furrow in his brow, saying "I think there's a real possibility"? Who had that been again? Reiko could only be amazed at how fast Inspector Kazamatsuri changed his tune.

\footnotetext{
${ }^{54}$ Shigeru Amachi: a popular actor who featured in a number of Japanese detective movies in the ' $50 \mathrm{~s}$ and ' $60 \mathrm{~s}$
} 
Eventually, when the two detectives made their way back to room 304, an officer ran up to Inspector Kazamatsuri like he had been waiting for him.

"We found these in the drawer of the victim's computer desk, sir."

He had a single photograph, and a key. The key was not one for this apartment. Though the building was old, they keys for these apartments were brand-new and well made, to prevent break-ins. The key in front of them now was clearly from somewhere else.

“Oh ho, what's this.” Inspector Kazamatsuri turned to the photo, instantly intrigued. "A picture of Hitomi Yoshimoto and a young man, huh? Yes, the victim was dating someone, wasn't she. If so, this must be his key-hmm, now this is interesting."

Reiko understood what the Inspector was implying. If, like it seemed, the couple had had a fight, the likelihood of the killer being a man was high for this case. Plus, a lover's quarrel was a very tempting motive.

"If he's the victim's lover, we have our probable suspect," Inspector Kazamatsuri said happily. "For now, let's have Eri Sugimura take a look." Then he dashed out of the room with the photo in hand.

Then, when they showed the photo in question to Sugimura, she exclaimed "Oh, him!" and then answered: "He worked at a company where Hitomi was temping six months ago, I think his name was Tashiro...Yuuya Tashiro.” 


\section{2}

And so, the next day_-Sunday_-Inspector Kazamatsuri and Reiko immediately went over to Yuuya Tashiro's apartment, then took him for questioning at a nearby coffee shop.

Tashiro was 33 years old-young for the general affairs manager of a mid-size appliance manufacturing company, but one of the company's elite employees. On closer inspection, Tashiro was dressed casually, like he had the day off. He was well puttogether, and seemed the type who would be popular with women. It was a definitely possibility, Reiko thought, that a temp worker like Hitomi Yoshimoto would have been drawn to his good looks and elite title. Reiko, of course, didn't feel any attraction to this level of looks or title. Naturally, if she were the type to react to things like that, she wouldn't be a fit partner for the heir to the Kazamatsuri Motors fortune.

True to form, when Reiko and Tashiro were about to order plain coffee, Inspector Kazamatsuri butted in and ordered three cups of Blue Mountain Special Select without asking and or even giving a guilty look. Then he began the questioning.

"Well then, Mr. Tashiro, can you confirm that you were dating Hitomi Yoshimoto, yes or no?"

"Yes, I can. We started dating about a year ago. We became friends right after she started temping at my company. But about six months ago we broke up. It just sort of ended naturally. She temped at my company for half a year, then moved on to a different company. We've haven't spoken since then." 
"I see. However, if that's so, why was Ms. Yoshimoto hanging on to a picture of you, I wonder? And not just a picture. She had this as well."

Inspector Kazamatsuri brandished the key from before under Tashiro's nose.

"Mr. Tashiro, this wouldn't happen to be your key, would it?"

Tashiro glanced at the key. "Looks like it is," he answered lightly. "What about it?"

“Then I'll ask you frankly: you and Ms. Yoshimoto had a serious enough relationship to exchange keys. You've said you broke up a long time ago, but the truth is that there was still something going on between the two of you, right? After all, she was still hanging on to your key. Am I wrong?"

"It's not true." Tashiro had been holding onto his calm, but now he raised his voice for the first time. "Yes, we exchanged keys. But the only reason she still has my key is that I just never had a chance to get it back after we broke up. That kind of thing happens all the time, right? Anyway, let's say you're right, that she and I were still in a relationship: what does that mean? Are you trying to say that I killed her?"

It seemed a bit early for him to be giving in, but at least that would move the conversation along that much faster.

"Now, now, it's not that we suspect you," Inspector Kazamatsuri said, the most popular line for this kind of situation, then fired off the question that was the real heart of the matter. "By the way, Mr. Tashiro, what were you doing yesterday evening?" "Looking for an alibi? Well," he snorted disdainfully, "that's fine. Fortunately, if you can call it that, yesterday evening I was out with some fishing buddies from work. 
We were down at Shonan Beach, in Hiratsuka. We left in my friend's car at noon and got to Hiratsuka around three. After that, we decided to indulge and just stayed out fishing until the middle of the night."

"Hmm, fishing in the middle of the night," Inspector Kazamatsuri said, a sudden smile in his tone. "Then you would've had it pretty rough last night, huh? It was raining in Hiratsuka — not too good for fishing, I'd say."

“Ha ha! It's no good trying to trap me, Inspector. Yesterday's weather report did call for rain over all of the Kantou area last night, didn't it? But the weather report was way off. There wasn't even a drop of rain in Hiratsuka. It didn't rain in Kunitachi either, did it? Right, Inspector?"

"Oh, yeah, now that you mention it..."

"Right? I had great weather for fishing last night. Then, we just spent the night in the car. I only got back to Kunitachi this morning. So, naturally, I was with my friends the whole time. By the way, Inspector, what time was Hitomi Yoshimoto murdered?"

Tashiro asked the question almost triumphantly. Inspector Kazamatsuri, on the other hand, looked like nothing was going according to his plans, and just sipped bitterly at the coffee the waitress brought them.

Afterwards, to collect evidence to prove Tashiro's testimony, Inspector Kazamatsuri and Reiko went around and spoke to Tashiro's fishing buddies. But this just ended up proving Tashiro's alibi to be completely true.

The pair returned to the Kunitachi Police Department well after dark, and flopped down into their chairs and didn't speak for a time. Already, they couldn't even muster the 
energy for a discussion. Then, Inspector Kazamatsuri's faint voice rose through the stagnant air.

"Well, well—looks like all we've done is prove that our number one suspect, Yuuya Tashiro, isn't the killer. We're right back at square one with our investigation. We'll have to start over again tomorrow. Oh, Hōshō_-" the Inspector turned to Reiko while loosening his tie. "You should go home already. You were here over night again yesterday, right? Working too much is bad for your skin, you know, Miss Hōshō."

"Yeah."

It was nice that he was looking out for her, but she really did hate being called "Miss Hōshō". You could say she was being contrary. Even so, she didn't have the energy to complain at the moment. She must really be tired. "Well, I'll take you up on that offer-I'm off for today."

"Ah, that's good. Well then, I'll just take you in the Jaguar-"

"No thanks!" Reiko refused flat-out.

Inspector Kazamatsuri, taken aback, dropped back into his chair with enough force to spin it completely around.

Reiko walked out of the Kunitachi Police Department alone. Kunitachi was proud of its stylish, clean streets, and stood out even among the other towns along the Chuo Line. ${ }^{55}$ But, in fact, city hall and the other public offices were actually closer to the Nanbu Line. So, while it could also be grouped with the towns along the Nanbu Line, the

55 The Chuo Line: the area surrounding the Chuo Line is considered by Tokyoites to be a fancy, respectable place to live. 
people of Kunitachi probably wouldn't have been pleased with this. The main thing was the problem of image, but that was another story.

While glancing at the city hall building out of the corner of her eye, Reiko turned her steps towards Yaho Station. Reiko could feel the deepening autumn in the cold wind blowing down from Musashino, and it felt nice against her tired body. But her head was still full of the investigation. If Yuuya Tashiro was innocent, Hitomi Yoshimoto's murder would seem to be a much more difficult case. For one thing, she didn't understand the motive. And she wasn't clear on how the crime had been carried out. On top of that, Inspector Kazamatsuri was the one in charge of this case. Reiko smelled a dead end.

Not that she was saying Inspector Kazamatsuri was incompetent. He was, of course, young for a detective. But if he would just listen to his subordinates a little more humbly, or if he were just a little more cooperative and careful—oh, and she wished he'd quit showing off with that nouveau riche attitude of his, and be less obvious with his sexual harassment. Come on, it's rude to call a working woman "Miss," isn't it? Who do you think you are, a cheesy talk-show host like Mino Monta?? ${ }^{56}$

“Oooh!” In a fit of anger, Reiko kicked at a little stone in the roadway. The stone then flew towards a car parked on the road - a black-painted import, a limousine that was almost seven meters long — and bounced off it with a dull ringing sound. Reiko's hands flew up to cover her mouth. "Oh crap!"

Immediately, the driver's side door opened and a tall, slender figure of a man stepped out. He appeared to be in his mid-thirties. He looked almost noble in his dark,

\footnotetext{
${ }^{56}$ Mino Monta: a Japanese celebrity known for his charming (if sometimes smarmy) personality
} 
funereal suit, or maybe like the doorman for a cabaret show. The man cast a sharp glance at Reiko through his silver-framed glasses and, without any change in his expression, knelt down next to the limo and inspected the damage.

Reiko came towards the man shyly, apologizing with a bow of the head. "I'm so sorry! How much will it cost to repair, do you suppose?"

"Please don't concern yourself. At the most it would be something like 70,000 or 80,000 yen." The man stood up calmly, as if nothing had happened, and gave Reiko a respectful bow. "It is only a scratch, Miss Reiko.",57

"Well, thank God for small favors, I guess," Reiko said with a little sigh, gazing at the black limousine. “Good thing it wasn't some stranger's car. By the way, Kageyama," Reiko addressed the dark-suited man again. "Did you come all the way out here just to pick me up?"

"Yes, Miss Reiko, I did. I thought you might be returning home about now." "You have pretty good hunches, huh. You could be a detective."

"Certainly not." The man she had called Kageyama shook his head repeatedly. “I'm just the Hōshō family's butler and driver. There's no comparison between myself and a talented noble personage such as you, Miss Reiko. I could certainly never do such a thing."

“As silver-tongued as always, aren't you," Reiko teased.

"Not at all, Miss Reiko, I assure you." Flustered, Kageyama put a hand to his silver-framed glasses. "At any rate, if you would take your seat, Miss Reiko."

57 お嬢様 
With the smooth movements expected of a butler, he ushered Reiko into the limousine. And Reiko, as daughter of the Hōshō family, should have gotten in gracefully with a bow and a "thank you," but what with all her hard work since yesterday, she was at the peak of exhaustion. She practically fell onto the cushioned seats head first. She couldn't have walked even one more step. “Hey, Kageyama, I'm gonna take a little nap back here, so just drive around some place for about an hour, would you?"

Even after such a selfish order, "Understood,” came Kageyama’s response from the driver's seat.

Reiko laid her body across the seats, stretching out as far as she could. Even so, there was still plenty of room on the L-shaped arrangement of seats. Before long, lulled by the pleasant rocking of the limousine, Reiko fell into a brief sleep. Hands steady on the wheel, Kageyama did as Reiko had ordered, driving around slowly for an hour or so, ending up at a certain grand-looking Western-style mansion - they had returned to the Hōshō estate.

Yes, Reiko Hōshō, was much more than just "Miss Hōshō”, the only female detective in the Kunitachi Police Department. She was the one and only "Miss Reiko" of the Hōshō estate.

After a very simple dinner of shrimp and lentil salad, seafood soup, chicken in stewed tomatoes, and lamb grilled with rosemary, Reiko went to relax in a large room with a sofa and a view of the city skyline. 
As a detective, Reiko usually wore a modest Burberry pants-suit, something plain anyone could have bought at the local department store, endeavoring to maintain the straight-laced image appropriate for a detective. However, once she was back in her own mansion, she often relaxed in a cocktail dress, or something more feminine. If Inspector Kazamatsuri ever caught sight of her like this, he probably wouldn't even realize he was looking at the subordinate he worked with everyday. Inspector Kazamatsuri didn't know that Reiko was the only daughter of Seitarou Hōshō, the founder of the Hōshō Group.

"Your father is very worried about your detective work, Miss Reiko," Kageyama said, pouring a finely aged wine into a glass that sparkled like a jewel. "He's so busy worrying that you might be down by the river in Tamagawa in a gunfight with vicious criminals, or running through Kunitachi carrying a bag full of ransom money, or in the middle of a car chase on the freeway-he can hardly concentrate on his work."

“Oh, really?" If he was caught up in such wild daydreams, how was he running his company, or even keeping up with the day-to-day? He really should go see a doctor. Poor old dad. "You can tell my father I'm fine and to stop worrying. The work I'm doing now has nothing to do with gun fights, or ransoms, or car chases. It's just your average murder-well, maybe it is a little strange."

"Strange, Miss Reiko?"

"It's just that the corpse still had shoes on-Oh, well, I guess if you assume that the corpse had the shoes put back on it, it's not all that mysterious. But what I don't understand is why they'd go to the trouble of putting shoes on a corpse, or why Hitomi Yoshimoto had to be killed, I don't understand the reason-do you, Kageyama?" 
“Oh no, not at all. Certainly not with that explanation." The butler shook his head slowly, regretfully, and for a moment his eyes disappeared behind the glare on his glasses. "However, Miss Reiko, if you would be kind enough to explain in a little more detail, I may be able to offer some of my own modest thoughts."

Reiko was quite surprised by his words. It hadn't even been a month since this young butler, Kageyama, had begun working at the Hōshō estate. So it was still difficult for Reiko to say she understood him very well, but if she had to describe him, he seemed the picture of sobriety and honesty; on top of that, he gave the impression that he tried to keep his thoughts and feelings to himself. She never would have thought him to be the type of person to "offer his own modest thoughts" on a criminal investigation. However, Reiko replied, "All right, then. I'll give you some more detail.”

So, she granted Kageyama's request. She was interested in what he thought, and talking it out with someone could also deepen her own understanding of the investigation, and might bring to light a point she had been missing up to now. Someone as serious and tight-lipped as Kageyama might even be the perfect partner in this kind of conversation.

"The crime took place yesterday around $6 \mathrm{pm}$, and was discovered around $7 \mathrm{pm}$. The victim was a twenty-five year old woman named Hitomi Yoshimoto-_"

Sitting on the sofa and occasionally refilling her wine glass, Reiko talked over all the details of the investigation, hiding nothing. It was a long story, but Kageyama stood straight and alert, as is befitting of a butler, and listened intently. Finally, with Yuuya Tashiro's alibi proven true and the investigation back to square one, Reiko came to the end of her story. 
"So, Kageyama? Did anything strike you? Anything at all, even something trivial is fine."

"Hmm." Touching his silver frames with his fingertips, Kageyama's expression was troubled. "Would you allow me, Miss Reiko, to share my thoughts?"

“Of course," Reiko said encouragingly, smiling kindly at her butler. "Please don't hold back. Say whatever you like."

"May I really say whatever I like?" the butler asked, double-checking. "Well then, I shall lay out my thoughts frankly." With that, Kageyama gave a deep bow, then sat down on the sofa and brought his face close to Reiko's. Then, he communicated his "modest thoughts" in very straightforward words.

"If you will pardon me: if you haven't understood something this obvious — are you an idiot, Miss Reiko?"

For a moment, maybe even minutes, silence reigned.

Reiko poured wine into her empty glass. Carrying the glass, she stood and walked quietly over to the window. From the high vantage of the estate, she could take in all of Kunitachi in one sweep of the eyes, lit up like rows of candles in the dark. It was a view she never tired of. Her heart felt peaceful. Alright, I'm fine, I'm calm, Reiko told herself, then took a little steadying breath and turned back to Kageyama, carefully opening her mouth.

"Fired, you're fired! Absolutely fired! Fired, fired, fired, fired, fired, fi_-" "Now, now, please calm down, Miss Reiko." 
"Like hell I'm going to calm down!" The hand that held her glass was shaking so hard that the red liquid inside was spilling over the edge. "I can't believe that a butler would try to make a fool of me - me! I've never heard of such a thing!"

“Oh, no, Miss Reiko, it was not my intention to make a fool of you..."

"Yes, yes, that's right!" Reiko nodded exaggeratedly, and began circling the butler. 'Certainly, you didn't make me a fool. After all, you called me an idiot, didn't you! Not a fool, an idiot—so you're done! Fired! Leave the mansion at once. Don't worry, your things will be sent along later. Go on, hurry up."

Reiko pointed to the door. Kageyama, ever the polite butler, gave a bow, and said, "Understood. Very well, I shall excuse myself," before turning quietly away.

However, just before Kageyama could leave the room, Reiko called out, flustered, to his retreating figure.

"W-wait just a moment."

"Yes, ma’am.” Kageyama turned smoothly back to Reiko, as if he had been expecting to be stopped. "Is there something else I can do for you, Miss Reiko?"

The nerve of this guy! Reiko bit the inside of her lip, trying to keep a straight face.

"You called me an idiot, right? Which means you're saying you've already figured out this case."

"That is correct. This investigation is not so difficult."

"You're awfully sure of yourself." Reiko glared bitterly at Kageyama. She found herself in a complicated position. As his employer, it was difficult to forgive her butler's behavior, but as a detective she couldn't miss the opportunity to hear Kageyama's story. 
Eventually, Reiko let the detective in her have priority. "You've come this far, so I'll have to listen to you, won't I? Who's the killer, then?"

"I cannot yet tell you who this killer is," was Kageyama's unexpected answer.

"Why? At this stage, Miss Reiko, even if I told you, I do not believe you would understand."

"What was that?!" These comments were even ruder than him calling her an idiot before. 'You're seriously saying you won't tell me who the killer is because I won't understand? No, I really don't understand it! I don't understand what you're thinking, not at all!"

Then, in her disappointment, Reiko uttered a phrase that was humiliating both as Kageyama's employer and as a working detective.

"Can you please explain it for me so I'll understand?"

As though he had just been waiting for those words, a little smile appeared on Kageyama's mouth, and he turned to Reiko again with a deep bow.

"Very well, Miss Reiko."

4

"One of the causes for confusion in this case is the testimony of the apartment's landlord: the man from the first floor, Kensaku Kawahara."

Reiko thought back on Kawahara's testimony. He had crossed paths with Hitomi Yoshimoto by the mailboxes, when she had been walking back from the train station. He had testified that it had been about $6 \mathrm{pm}$ at the time.

"I don't think it was a particularly strange testimony, though." 
"Then let me ask you this: when Hitomi Yoshimoto ran into Kensaku Kawahara, why did she not check her own mailbox? People returning from an outing almost always do so, I believe. Don't you think it a little odd, Miss Reiko?"

"Hm? That's__" Reiko could not find a good answer to this unexpected question. "That-it's just that she forgot, right?"

"That could be. Then I have one more question: when Kawahara greeted her with 'welcome back,' why did she look troubled and give a vague reply? It is not so difficult to answer such a greeting, I think. Cannot one usually return with 'I'm home'?”

"That's certainly true. Kawahara thought it was strange, too. Then, why do you think she didn't do that, Kageyama? Tell me what you're thinking."

"Kawahara testified that he "crossed paths with Hitomi Yoshimoto on her way home,' but that was not the case."

"What?! Well who the heck did Kawahara cross paths with, then?"

“It was Hitomi Yoshimoto, of course.” The butler seemed to dodge Reiko’s sarcasm. 'However, it was not 'Hitomi Yoshimoto on her way home,' but think instead that it was 'Hitomi Yoshimoto on her way out."'

"What are you saying?! Hitomi Yoshimoto came from the direction of the station, passed Kawahara, and went up the stairs. Clearly she was coming home, right?"

"Not necessarily, Miss Reiko. Going back to the house does not necessarily mean one is returning home. It is frequently the case that one must go back home in order to go out." 
“Going back home in order to go out..." Somehow his phrasing seemed paradoxical. "What do you mean?"

"For example: a businessman on his way to the office might realize at the station ticket gate that he's forgotten his train pass and will head home temporarily. A child on the way to school may realize she's forgotten her textbook and go back to the house. Even the famous housewife, Sazae-san, on her way out to go shopping might forget her wallet and have to go home again. These are just some of the many ways people can find themselves returning home in order to go out. It is likely that Hitomi Yoshimoto, too, was in the middle of such a situation — going home in order to go out. If we think in this way, we can neatly answer our previous question."

“Oh.” Of course: naturally, someone planning to go right back out wouldn't think to check their mailbox. Even if greeted with "Welcome back," someone planning to go right back out wouldn't be able to say "I'm home," and might give a vague reply. "When you put it that way," Reiko said, "it seems right on the money, doesn't it."

“As expected, Miss Reiko, you catch on quickly." Kageyama gave a short, respectful bow. "In that case, perhaps you have already figured it out, the truth behind those noisy footsteps 'like someone running down the stairs'? The ones Yasuo Moritani, the college student on the second floor, heard?"

“Ummm...well, they weren't the killer's footsteps, right?"

"Indeed. Not at all the footsteps of a fleeing killer, but in truth no more than the sound of Hitomi Yoshimoto's booted feet as she hurried out." 
For a moment, Reiko was stunned. "Yes, of course I knew that," she lied quickly, to cover her pause. "Yes, yes, that's right. It's hard to imagine that the killer would overlook something like that, making such a loud noise while fleeing the scene. It certainly fits our story if the footsteps that college kid heard were the footsteps of Hitomi Yoshimoto as she left," Reiko said, finishing her summary of their deductions so far.

“And so," she continued, "at 6pm last Saturday, Hitomi Yoshimoto was not returning home, but instead, was on her way out. However, on her way to the train station, it turns out she remembered something she'd forgotten at home, and returned to the apartment a few minutes later. But, if that's so, what was it she forgot I wonder?”

"Now, that is something I cannot clearly tell you either."

That was understandable. What would the victim usually have carried that she would have forgotten on that day? Even Reiko didn't have a butler who could figure out something like that. The victim had had her wallet, her cell phone, so Reiko knew it had to be something else- — while she was thinking all this, Kageyama said something unexpected.

"From your story, Miss Reiko, there was just one thing that we can clearly assume Hitomi Yoshimoto forgot. Perhaps we can assume she returned for that reason.”

“Huh? What? What was it?" Reiko's head was spinning. Where in her story had there been the suggestion of something Hitomi Yoshimoto had forgotten? Reiko herself had no idea. "Where was there something she forgot?"

"On the veranda," Kageyama said, as if he had seen it for himself. 
"The veranda!? Well, yes, there were a lot of things on the veranda—shirts, jeans, underwear, even tennis shoes—but which one was the one she forgot?"

"It was all of those things," Kageyama replied, gazing at Reiko. "Do you remember, Miss Reiko, the weather report for Saturday night?"

"The weather report!? Well, it said that there would be rain for the whole Kantō area—but in the end it didn't rain—so, then, the thing she forgot was...!"

"Yes. What she forgot was the laundry on the veranda. More precisely, she forgot to bring in that laundry. However, once she left the apartment and began walking to the train station, perhaps she noticed the ominous look of the sky and remembered the weather report, as well as the laundry on the veranda. Then, we can assume she turned back, returning to the apartment by the very road she had just come down."

"Of course. That all fits." At first, Reiko was impressed - then a very basic question came to mind. "But, if you think about it, there's not much point to all your deductions. After all, whether the victim was killed after returning home or after returning to bring in the laundry, it's all the same, isn't it?"

"Not so. This is a problem concerning the boots you mentioned earlier."

"What do you mean?"

“Try to put yourself in the victim's place. Let us say that you, Miss Reiko, had laced up your boots and gone out only to recall that you had forgotten to bring in the laundry, and so returned home. What would you do once you had stepped back inside?" "What do you think I'd do-I'd call you and order you to bring in the laundry." 
“Oh..." Kageyama seemed momentarily at a loss for words. "Yes, that is true. That is certainly what you would do, Miss Reiko." He nodded as if he was a bit impressed, stroking his chin with his fingers. "However, Hitomi Yoshimoto did not have a butler like me. What do you think she would have done?"

“There's no question of what she would have done-she would have taken off her boots, gone inside and over to the veranda and brought in the laundry. That's all she could have done."

However, Kageyama shook his head slowly from side to side.

"I'm sure there are very many people who would do just that. Still, on the other hand, there is a fair number of people who would feel that method was inefficient and chose another way. In a way, it is something that would be quite alien to you, Miss Reiko, so it is not surprising that it did not come to you right away."

“Alien to me?" Really, nothing was coming to her. "What way is it, then?"

"Really, it's very simple. First, with her boots on, she would have got down on all fours. Then, supporting herself on hands and knees and keeping the bottoms of her feet from touching and dirtying the floor, she would have crawled forward on all fours, like a dog. Crossing a longer distance may have been difficult, but in a one-room apartment this is not such a bad way to go about it. It might have looked bad, but perhaps she was unconcerned, as she was living alone. Most of all, in this fashion, there was no need to go to the trouble of removing her boots. As you said, Miss Reiko, it is very bothersome to be taking such boots off and on, so there is a great advantage to this method. Perhaps Hitomi Yoshimoto did not want to expend the effort of taking off the boots, and decided to do 
this instead. She crawled across her small room on hands and knees, dog-like, and into the inner room with hardwood floors-with her boots still on."

"Wait, so you're saying that Hitomi Yoshimoto entered the hardwood floor on her own. So she was killed there, not carried in by someone, right?"

"Yes. She was not killed and then carried. Hitomi Yoshimoto entered the hardwood room herself, and there someone strangled her from behind, and killed her. Surely she was surprised. Since there was someone in a room where she expected no one to be. However, as she was on her hands and knees in any case, she couldn't have been prepared to fend off her attacker. Therefore, she was killed easily, without even time to scream. And now, we have solved the strange problem of a girl being killed in her room with her boots still on."

“So...so that's what happened?" Reiko was astonished by Kageyama’s deduction. There was still the fact that he had called his employer's daughter an idiot. It kind of made her mad, but she would just have to deal with it. "But, surely, no one could know who the murderer is, right? Not even you."

"Oh, no - if my deductions so far are correct, I have a good idea of who the perpetrator is. May I, Miss Reiko? Hitomi Yoshimoto was going out and left her apartment briefly, and returned a few minutes later. The murderer must have broken into Hitomi Yoshimoto's room, number 304, in the space of those few minutes. This much we agree on?"

"Yes, fine." 
"Still, her apartment key is a new model made to prevent break-ins. Not the kind of antique a cat-burglar could open in a few minutes."

"Yes, exactly. I can’t imagine that the murderer broke into the apartment."

"Then perhaps Hitomi Yoshimoto forgot to lock her door? However, according to your story, the likelihood of that is low. 'Hitomi Yoshimoto was much more careful than other people about making sure the door was locked, and would never have forgotten to do it,' just as the first witness, Eri Sugimura testified."

“That's certainly true. It's more likely that Hitomi Yoshimoto locked the door when she went out."

"Regardless, the perpetrator was able to break-in very easily in a short amount of time. This can only lead us to one conclusion. We must assume that the murderer had a copy of the key to apartment 304."

"A copy..." With those words ringing in her ears, a single person floated up in Reiko's mind. A man who had exchanged keys with Hitomi Yoshimoto. "Yuuya Tashiro — was he the murderer after all, then? Oh, but that's impossible, Kageyama. He has a perfect alibi."

"Correct. Yuuya Tashiro is not the murderer."

“Then it's not the landlord, Kensaku Kawahara, surely? He would've had a copy of the key, though."

"However, after meeting Hitomi Yoshimoto in front of the newspaper box, Kawahara went straight back to his own room. That is clear from the testimony of the 
fruit-stand owner from across the street. It is impossible that he entered Hitomi Yoshimoto's room first and then attacked her."

"Well then, what the hell happened? The killer was someone with a copy of the key. But there was no chance for the two people who had copies to have committed the crime. In that case, we're out of suspects, aren't we?"

"No, Miss Reiko, there is one more suspect. Just one more person who would have had access to a copy of the key. And it is that very person who is Hitomi Yoshimoto’s real killer.”

Reiko felt a rush of nerves at Kageyama's decisive words.

"So who is it? Someone I don't know about?"

"No-it is in fact someone you already know. Or, more precisely, I should say you know that person's shoes."

"Their shoes?"

"Have you forgotten, Miss Reiko? The white shoes in the entrance way when you visited Yuuya Tashiro’s room?"

Suddenly, the scene from the visit to Tashiro's apartment came vividly to Reiko's mind. In the mess of men's shoes in the entrance, there had certainly been a pair that seemed out of place.

“The white heels!" Reiko shouted without meaning to. "You're saying those were the shoes of the real killer!?"

"That is correct," Kageyama replied calmly. "As you guessed, Miss Reiko, those white heels may very well belong to Yuuya Tashiro's new girlfriend. And if she is his 
girlfriend, it is likely she was able to come and go freely in his apartment. This means that, while Tashiro was out, we can assume she was able to secretly take and use Tashiro's copy of the key to room 304."

"That's it. Tashiro was out fishing on Saturday night! The woman with the white heels could have easily used Tashiro's copy of the key!"

“Just so, Miss Reiko. From here, I’ve had to use my imagination a bit, so please keep that in mind. This woman-well, as we don't know her name, shall we call her Ms. Whiteshoes for the time being?"

"Sure, the woman in white heels, Ms. Whiteshoes."

“Let us say Tashiro's new girlfriend, Ms. Whiteshoes, somehow finds the key he had been keeping hidden. Naturally she does not know whose apartment the key goes to. But she is clever. Finding that key, Ms. Whiteshoes imagines that Tashiro is seeing someone else behind her back, that this must be that woman's key, she begins distrusting him. If so, Ms. Whiteshoes would naturally want to find out who this other woman is. Then, she does everything she can to find out, or perhaps she already knew about Tashiro's old girlfriend. I cannot say for sure, but at any rate, she comes to suspect Hitomi Yoshimoto. And so, how can she find out whether there is something going on between Tashiro and Yoshimoto? Here, she comes up with a good plan. While Tashiro is out of the house, she'll take his copy of the key and try it on Hitomi Yoshimoto's apartment door. If it fits, their relationship will be clear. Then she put her plan in motion." "And that was Saturday, right?" 
"Yes. Ms. Whiteshoes waits for Tashiro to leave on his fishing trip, takes the key from his room, and heads to Hitomi Yoshimoto's apartment. Then, she watches Yoshimoto's apartment from a parked car, perhaps, and waits for Yoshimoto to go out. With the inhabitant inside, Ms. Whiteshoes is hesitant to test the key in the lock. Finally, after a time, 6pm comes around and Yoshimoto finally leaves her apartment. Key in hand, Ms. Whiteshoes goes into the building right away. She finds room 304 and tries the key in the lock. Naturally, it opens the door. And now, Ms. Whiteshoes has succeeded in finding that 'other woman' she was looking for."

"Which was her goal all along. The problem comes after that."

"Indeed. If she had stopped here, perhaps there never would have been an incident. However, convinced that Hitomi Yoshimoto would not be returning for a time, Ms. Whiteshoes took the freedom of entering the apartment. It might have been that she was curious to see how the 'other woman' lived, or to find further proof of her boyfriend's cheating. But then something happened that she was not expecting."

"Hitomi Yoshimoto came back, right after having gone out. To bring in her laundry."

"In the middle of the break-in, the inhabitant of the apartment returned. Perhaps that was all that was needed to send Ms. Whiteshoes into a panic. She cannot help but be mistaken for a thief. What's more, this is her boyfriend's mistress. There would be no greater humiliation than being found like this. It could end her relationship with Tashiro. That and her position in society_ assuming she held such a position — could only be damaged. Perhaps Ms. Whiteshoes tried to think of a way out of her predicament. 
However, there was nowhere to run in the one-room apartment. The next moment, in the midst of her frantic attempt to escape, a completely unexpected scene unfolded before her. There was Hitomi Yoshimoto, crawling into the room on all fours, still in her boots. In the face of such defenselessness, it is perhaps not so strange that Ms. Whiteshoes called on violence as a last-ditch emergency measure."

"She just made a preemptive strike before there could be a commotion."

"Ms. Whiteshoes found a rope nearby. Perhaps there was a vinyl cord off of a newspaper, left near the bin. Then she attacked Hitomi Yoshimoto out of desperation. Since it was never a calculated crime, we cannot be sure if she really had intent to kill. But her jealousy strengthened her grip: in the end, Ms. Whiteshoes strangled Hitomi Yoshimoto to death - or, we can imagine that the rough outline out the incident is something like this."

With his explanation finished, Kageyama turned to Reiko with a quiet expression. "What do you think of it, Miss Reiko?"

“Oh—t-that's right, I guess. It's pretty good. It seems like the killer really was the woman with the white heels." Honestly, it was more than just "good." Reiko thought Kageyama's deduction was pretty much perfect. She hated to say it, but the killer's actions and the victim's must have been exactly as Kageyama had described. But it annoyed her to admit it so easily, so instead she asked a few more questions.

"We didn't find any strange fingerprints at the crime scene. I wonder if the killer was wearing gloves?" 
"The act of going into someone else's house without permission is itself a crime. So, as a precaution, the perpetrator likely was already wearing gloves just to unlock room 304. In the end, the perpetrator was able to get by without leaving any fingerprints even after she became a murderer."

"But when Hitomi Yoshimoto came back to the apartment, the killer's shoes should have been at the entry way. Did she just not notice them?"

“According to your story, Miss Reiko, Hitomi Yoshimoto’s apartment was not especially well organized. Surely the entryway was just as messy. So we can assume she would not have noticed if there had been a strange pair of shoes there."

Apparently Kageyama had completely satisfactory answers for all of Reiko's questions.

"Yes, you've really got it figured out," Reiko said with a big nod. "Then I have just one more question for you." To close out the evening, Reiko threw a question at Kageyama that had been bothering her the whole time. "Who are you, Kageyama? Why are you so good at figuring things out? Why are you working as a butler?"

Kageyama lightly adjusted his silver-framed glasses, and answered very earnestly. "Really, I wanted to be a professional baseball player, or a professional detective." Disappointed, Reiko thought, What kind of answer is that? 


\section{Chapter 2: Would You Care for a Glass of Poisoned Wine?}

When Reiko Hōshō woke up, the hands of the clock next to her bed were pointing to just before 7am. She was impressed with herself - this was thirty minutes earlier than she usually woke up. It was a minor miracle that she was awake at all, without the help of the alarm clock. Usually she didn't even notice when it went off, or she went right back to sleep. Recently, the morning pattern was for Reiko to fly out of bed at the sound of Kageyama's knock on the door just as she was about to be late. (Kageyama was the one of the many servants of the Hōshō estate. Though only in his thirties, he held the respected position of butler and chauffeur, and furthermore the man was also priceless as a human alarm clock. Such a personage was one seldom seen outside of the Hōshō household.)

"I have got to go brag to Kageyama about this, since I'm up so early."

With this simple goal in mind, Reiko put a light gown over her pajamas and left her bedroom.

The season was spring. Even so, the April mornings were still cold. The air in the hall was chilly and refreshing against Reiko's sleepy face. By happy chance, she found Kageyama in the hallway. Even first thing in the morning he was wearing a dark suit—all he needed was a pair of sunglasses and he'd look like someone right out of a gangster movie. But the real Kageyama wore his favorite pair of slightly old-fashioned silverframed glasses, maintaining an appearance of intelligence. This Kageyama was a butler and, as soon as he saw Reiko, he bent his tall frame in a bow and delivered a proper morning greeting. 
“Good morning, Miss Reiko. I trust you slept well last night?"

"Yes, even better than usual."

“Splendid," Kageyama nodded, keeping his face blank and adjusting his silver frames slightly. "Incidentally, I take it Miss Reiko did not have any troubles last night?" What a strange question.

"Not really—why, did something happen?"

“Only a spring storm. It seems there was some lightning that caused a power outage for about an hour and forty-two minutes."

“Oh, I didn't notice.” But, Reiko wondered, how could he know the exact length of a power outage that had happened in the middle of the night? "How come you know so much about it?"

"Ah, well. The analog clock next to my bed is plugged into an outlet_-"

"Well, yes, so is mine."

"When I awoke this morning, the clock was an hour and forty-two minutes behind."

"Oh. So the amount of time the clock was stopped for was the length of the outage." Reiko nodded a few times, impressed, but then her face froze. She was silent for a long moment. Then she grabbed Kageyama by his necktie with both hands, spun him around and slammed him against the wall.

“Out with it, Kageyama: it is 7am right now, isn't it?"

"No, it is not seven o'clock." Kageyama lowered his eyes sadly. "I am afraid it is very nearly forty-five minutes past eight o'clock." 
"Ei-eight forty-five!"

If she were a high school girl in a comic, this would be where Reiko ran out of the house with a piece of toast clenched in her teeth. Fortunately (or perhaps unfortunately), Reiko was not a high school girl—she was a grown woman with a job. And here she was, standing around the house at 8:45am in her pajamas. Crap. There wasn't a moment to lose. In a panic, Reiko mustered all the wit and privilege she possessed and decreed her emergency instructions to the butler standing before her.

"Kageyama - bring the limo around front as fast as you can!"

Reiko Hōshō, as it turns out, was the only daughter of Seitarō Hōshō, leader of the Hōshō Group, known around the world for everything from financing, electronics, and pharmaceuticals, to even mystery novel publishing. Brought up like a princess, a graduate of the finest of universities with the finest of grades, she was a genuine aristocratic lady who wanted for nothing. And yet, that lady was the same girl from just a moment ago. Reiko couldn't bear the wifely pursuits her father encouraged for his beloved, sheltered daughter. But, on the other hand, working at the family company just to fill the time? Yuck. So, what she had chosen in the end was a fairly stuffy government job - that is to say, she worked with the police.

Reiko was detective at the Kunitachi City Police Department in Tokyo's Tama district.

Almost no one at the office knew that Reiko was the daughter of Seitarō Hōshō, except some of the higher ups. All of her other co-workers thought she was just a 
completely average, if pretty, young detective. (Reiko couldn't help it if that was just the truth.) And so, when she overslept and ran late, she didn't receive any special treatment. “Hurry up, Kageyama!” Reiko shouted. "Step on it! Just don’t break the law!” Reiko - the only person who ever issued Kageyama such absurd orders — then used all the space she had in the limo to change from pajamas to work clothes at top speed. Her pantsuit was an outfit for a go-get-'em girl: chic and elegant, delicate but functional. It was limited edition and had cost her several hundred-thousand yen at the Burberry boutique in Ginza - although she told all her coworkers she had gotten it on sale at the Marui superstore in Kokubunji for thirty-thousand yen. Since none of her male coworkers knew anything about brands, they all bought her story.

After she finished changing, she fixed her hair. A woman's hair is her glory, as the saying goes, so Reiko kept her hair a bit long for a detective. At work, she simply pulled it back in a boring ponytail. It was her very grown-up opinion that having shiny, nice-smelling hair never hurt when working with hard-hearted criminals.

However, if one didn't count the decorative Rado Integral Jubile (that is, the very finest in watches) on her wrist, Reiko never wore jewelry to work. But, starting today, Reiko was thinking she would add just one accessory. She pulled something from the case in her hand and held it up to her face.

Glasses by Armani-but no prescription in the lenses. They were a pair of socalled "fashion glasses."

\footnotetext{
${ }^{58}$ for ダテ眼鏡 ダテ from the use of 立てる as “make a fuss of/over something”, but also related to the Sengoku era Date clan who were known for putting on airs when appearing in court.
} 
the look of a fashionable grown-up woman. Or at least that's what the shopkeeper had said; Reiko wondered if that was true. Donning them timidly, she checked the rearview mirror and waited for an opinion from the driver's seat.

"So? What do you think, Kageyama?"

The butler's expression of surprise was barely visible in the mirror, but the limousine swerved for a moment.

"Is something the matter, Miss Reiko? Your eyes, at least, are just fine, are they not?"

“They're fakes, fashion glasses. I thought I'd try a new look for work. 'Cause, you know, it's probably better for a detective to look smart, so...."

There was, in fact, a reason Reiko had suddenly thought to try wearing glasses. The truth was, there was a completely insensitive man who had recently called Reiko an idiot right to her face. This particular man did have one thing to brag about in his astounding deductive skills. He had perfectly solved the case that Reiko had been struggling with by only listening to her describe it. And sitting on the bridge of his proud nose had been a pair of silver-framed glasses that were impossible to miss. Ever since then, Reiko couldn't help but think that there was some connection between his glasses and his smarts. But all that aside...

"Wait a second, why did you say 'your eyes, at least' just now?"

“Oh no, I said nothing of the sort. Perhaps you misheard me?” Kageyama’s face in the mirror was nonchalant as he pushed up his silver-framed glasses. "At any rate, they suit you very well. They are quite lovely." 
"You're not going to satisfy me with a compliment as boring as that. Try again." "Our styles seem to be overlapping a bit, but..."

"So what!" Kageyama couldn't be the only character in this story who wore glasses. "Oh well, maybe I'll give up on glasses. It seems like they don't really suit me at all."

“...Even hardened criminals would fall to their knees before you and begin confessing?"

"What, that's supposed to sound appealing?? Get to the point."

"My humblest apologies: I cannot possibly express your exceptional charm with my simple vocabulary, Miss Reiko. Please forgive me.”

“Oh.” Now, that was a little more like it. Especially the "exceptional charm" bit. "Very well, I suppose you've earned my forgiveness." From the driver's seat, Kageyama gave a small, long-suffering sigh. Just then, Reiko's cell jingled out her ringtone. As soon as she picked up the phone, she heard: "Hey, mornin', Miss Hōshō!"

With those words, Reiko already knew who was on the other end of the line: Kazamatsuri, the young Inspector of Kunitachi Police Department, and Reiko's boss.

"Where are you and what are you doing?"

Of course she couldn't just say "Oh, I'm in my limo, I just finished changing." Reiko paused to think of a reply, but Inspector Kazamatsuri starting talking without waiting for an answer. 
“Well, doesn't matter. What's more important, Hōshō, is that there's been an incident at the veterinary clinic on Asahi Street, second district, ${ }^{59}$ east Kunitachi. There's been a report that the head veterinarian was found dead in his room. You know Wakabayashi Veterinary Clinic, right? Alright, well, I want you to head straight there. I'll be there soon."

"Huh??" I can't show up at a crime scene in this car... "I mean-yes, understood." “Take me to the Wakabayashi Veterinary Clinic, quick!” Reiko ordered Kageyama as soon as she hung up the phone. Then she imagined herself pulling up to a crime scene full of patrol cars and rubberneckers in her limousine, and shuddered. "Actually, let me off about a hundred meters from the clinic. I'll walk from there." "Understood." Kageyama gave the wheel a big turn, and changed the limo's course.

Kunitachi Station was famous for the three roads that radiated off the roundabout out front— but really the only road that anyone knew about was the middle one, University Street. For the others, people just said stuff like "the road that goes right (or left) once you leave the station". Asahi Street was the one that ran diagonally to the left from the station (the other was Fuji View Street).

The sign for Wakabayashi Veterinary Clinic stood a little ways from where Asahi Street ended in front of a convenience store. The patrol cars and rubberneckers were all crowded in front of the clinic, just as Reiko had predicted. While she was still unnoticed, Reiko searched for the metallic silver Jaguar. The Jaguar was Inspector Kazamatsuri's

${ }^{59}$ for “二丁目” 
favorite car, and always made a conspicuous presence at the crime scenes in Kunitachi. Inspector Kazamatsuri never drove domestic cars. As he put it, "they make you look poor". This was something of a contradiction, as Inspector Kazamatsuri was himself the heir to Kazamatsuri Motors, a "poor-looking” domestic auto manufacturing company. But that was beside the point — when Reiko looked around, she saw no trace of the Jaguar. “Strange. I wonder if the inspector's not here yet?” Ducking her head, Reiko made to walk under the police tape, but then she straightened up...

"What the-?"

Suddenly, a mysterious object, shining like a mirror reflecting the sun, came into Reiko's field of vision. It approached with a roaring sound. She barely had time to realize it was Inspector Kazamatsuri driving his silver Jaguar. The car came flying at her-Reiko was sure he was going to run her over-but then, the Jaguar stopped right in front of her with a screech of tires, back wheels swerving madly. The driver's side door opened, revealing Inspector Kazamatsuri with a piece of toast clenched in his teeth.

“Hey, Hōshō, good mornin'!” he said, waving his free hand.

What are you, a high schooler in a comic! Reiko wanted to say, but held her tongue, instead choosing words more appropriate to her position. "Oh, er...what happened, Inspector?"

"It's a long story," Kazamatsuri said, stuffing the rest of his toast in his mouth. "See, I've got a plug-in alarm clock by my bed and-"

“Oh, I see. Never mind.” After about three seconds, Reiko had lost interest in his answer and coolly turned her back. "Well, shall we go ahead inside?" 
“C'mon now, if you ask 'what happened', you can't just say 'never mind', that's rude, you know! In that case, I've got a question for you: what's with those glasses? You trying to get someone's attention? Now, me, it's not that I hate girls with glasses or-hey, Hōshō-!"’

God, he's so irritating. "Trying to get someone's attention”- as if!

Ignoring her boss, who was still trying to catch up, Reiko stomped off angrily under the police tape.

\section{2}

The incident had taken place at the Wakabayashi residence, right next door to the clinic, in a room on the second floor. The victim, an elderly man, seemed to have died after collapsing from a chair by the window in his room. An officer walked over to the Inspector and explained the situation.

"The deceased is Tatsuo Wakabayashi, age sixty-two. The housekeeper discovered the body. She said she started to worry when he took so long to wake up and went to check his bedroom, and then found him like this."

Eyes glinting behind her fashion-glasses, Reiko quickly scanned the scene of the crime.

Tatsuo Wakabayashi had a lightweight robe over his clothes, very casual. His expression, however, was horribly distorted, showing the pain he had been in when he died. There were no external wounds that she could see, and there was no blood.

About ten centimeters from his left hand, a tulip-shaped wine glass had fallen to the floor. The glass was empty, but was at the center of a wide, red stain in the carpet. By 
the chair where Wakabayashi had presumably been sitting, there was a small table, and on the table, an uncorked wine bottle on a tray. Most of the wine was still in the bottle. Also on the tray was the cork itself, a T-shaped corkscrew, and the curled-up foil that had sealed the mouth of the bottle.

“Look, Hōshō,” Inspector Kazamatsuri called loudly. “Tatsuo Wakabayashi was having some wine before bed."

“...Yes, he was.” Inspector Kazamatsuri really was a pro at taking an observation anyone could have made and making it sound like his very own discovery. But if Reiko complained about it every time, she'd be out of a job. "Oh, what's this?"

Reiko pointed to the one item on the tray that stood out from all the others. It was a little brown bottle, like one that might be found in the clinic. There was no label. And it was empty. But, she could see there was a powdery substance stuck to the inside. Could it have been poison? Just as Reiko had that thought...

“Don’t you get it, Hōshō?” Inspector Kazamatsuri said, already settled on his conclusion. "This has got to be poison. Looking at the circumstances, there's no mistaking it."

Reiko didn't need the Inspector to tell her: just looking at the scene of the crime, it was easy to imagine that Tatsuo Wakabayashi had died after drinking something poisonous. Plus, the results of the forensic analysis that had already taken place had backed that up.

According to forensics, the cause of death had been poisoning from a type of hydrogen cyanide. There were no obvious wounds on the corpse, and no signs that he had 
fought with anyone. The estimated time of death was the middle of the night, sometime around $1 \mathrm{am}$.

The forensics analysis had not detected any poison inside the wine bottle, but traces of potassium cyanide ${ }^{60}$ had been found in the liquid soaked into the carpet. It had also been confirmed that the powder on the inside of the brown bottle was the same potassium cyanide. The victim's fingerprints were all over the wine bottle, the glass, and the little brown bottle; no other fingerprints had been found.

And now there were reports that a mysterious limousine had been spotted on the streets nearby, but Reiko knew better than anyone that that had nothing to do with the crime...

“Of course, of course,” Inspector Kazamatsuri said, nodding happily. Then, turning back to Reiko: "What do you think, Hōshō?"

From her first glance at the crime scene, Reiko had had the impression that, rather than a violent murder, this was the more or less common suicide of an aging man. But just as Reiko opened her mouth to say so...

“From what I've seen, I'd say Tatsuo Wakabayashi killed himself," Inspector Kazamatsuri said, making it clear that he hadn't had an interest in anyone else's opinion in the first place (and really, that was Reiko's opinion). "Perhaps Tatsuo mixed the cyanide from the small bottle into the glass of wine and took a big drink. That cyanide

\footnotetext{
${ }^{60}$ A note on the differing chemical names: hydrogen cyanide is the highly toxic chemical from which potassium cyanide is manufactured. Meanwhile, potassium cyanide is commonly used in the manufacture of pharmaceuticals.
} 
was definitely taken from the medicine cabinet in the clinic. As the head of the clinic, it would have been easy for him to do."

“Mmm." Reiko mostly agreed with this, so she didn't feel the need to object. "Just as you say, Inspector. If he had left a will, there would be no question, but..."

“Hmm, there doesn't seem to be a will, huh. But it's not so strange for someone to commit suicide without leaving a will, either. At any rate, I guess we should talk to the family he left behind, shouldn't we?"

It seemed to Reiko that Inspector Kazamatsuri had already made up his mind that this had been a suicide. So maybe, Reiko started to think, this wasn't a suicide after all.

Soon, the members of the Wakabayashi family were gathered in the parlor. When Inspector Kazamatsuri and Reiko joined them, a gentleman in late middle-age, who looked very similar to Tatsuo Wakabayashi, suddenly spoke.

"Detective, do you think perhaps my brother committed suicide?"

The man's name was Teruo Wakabayashi. He was the deceased Tatsuo's younger brother by only a year, and had already passed sixty. He was a veterinarian, and he had managed the Wakabayashi Veterinary Clinic with his brother, Tatsuo. He was a lifelong bachelor, and lived alone in an apartment near the Wakabayashi home. However, last night he had been staying over at the house, and so he' $d$ been present for the uproar this morning.

Teruo was slouched deeply into an armchair and had a pipe in his left hand- the old-fashioned kind, like something Sherlock Holmes would have used. He seemed to be struggling desperately to resist the urge to smoke. 
"No, we can't say yet that it was suicide."

Inspector Kazamatsuri put his own conclusions aside for the moment, and carefully sidestepped Teruo's question.

"If you're saying it wasn't suicide, are you suggesting it was murder, Inspector?"

This came from the loveseat, where Tatsuo's eldest son, Keiichi, sat. Keiichi was thirty-six. He had a wife and child, and he was a doctor-but for people, not for animals. He was a physician, and he worked at the general hospital in town.

"I didn't say it was murder. I'm just saying that we can't dismiss murder as a possibility at this stage."

“Oh, Inspector, what an awful thing to say. Surely there's not a single person in this house who hated my father-in-law."

From her spot next to her husband, Keiichi's wife, Harue, spoke sharply, providing her husband with some cover fire. At thirty-seven, Harue was a year older than Keiichi. They had met when she was working as a nurse at the hospital where he was employed.

'Now, ma'am, I'm not saying that anyone here killed Tatsuo. Unless, that is, you have reason to believe someone here did?"

Inspector Kazamatsuri looked around, challenging. As he did, a young man who had been leaning against the wall in the corner spoke up in a glum voice.

“Inspector, Dad killed himself. Everyone here knows that. You do, right?” 
Hearing the young man raise his voice at them, Keiichi and Harue exchanged an uncomfortable glance. Teruo knit his brows for a moment, then barked, "Knock it off, Shuuji."

The young man was the deceased Tatsuo's second son, twenty-four years old, and Keiichi's younger brother by almost ten years. He was currently attending medical school, commuting from the family home to school.

Sensing the uncomfortable atmosphere, Inspector Kazamatsuri pressed on.

"It seems like you all have a reason to believe Tatsuo would have taken his own life. Could that be because something happened between all of you and Tatsuo last night?" Inspector Kazamatsuri asked.

As the eldest, Teruo spoke for everyone.

"The truth is, Inspector, we held a kind of a family meeting last night. My brother and I, and Keiichi and Harue, as well as Shuuji, there."

"Oh, and just what was the occasion?"

"It's not really something I can talk about in front of strangers." Teruo ran a hand over his graying hair, and then stuck his pipe in his mouth as if he were embarrassed. Then, he pulled a small matchbook from his breast pocket and, with smooth movements, lit the pipe, only realizing what he'd done a moment later. "Do you mind if I smoke?"

"No, that's fine," Inspector Kazamatsuri said, keeping his expression cool as he watched Teruo. "That's rare, though, to see a pipe nowadays-I have a taste for cigars, myself," he continued. What a weird thing to brag about. 
Using her work gloves, Reiko subtly fanned at the drifting smoke. Tobacco smoke was not one of her favorite things.

"I must look like a Sherlock fanatic, like this. I made up my mind that after I hit sixty I'd start smoking a pipe. It's pretty nice. Recently, I hardly ever put it down. Well, what were we talking about again?"

"Cigars."

"No, Inspector," Reiko hissed. "We're talking about the family meeting."

"Ah, that's right," Teruo said, taking the pipe from his mouth, and instead of answering, asked a question: "What would you say, Inspector, if I told you my brother was thinking of getting remarried?"

“Tatsuo, remarried?? But he was already sixty-two, wasn't he?"

“Yes, but since his wife got sick and died ten years ago, he's been single, so it wouldn't be a problem if he were to marry someone else."

"So, there was someone who wanted to marry him?"

"Yes. We only found out about it very recently, but actually, my brother was thinking of getting remarried to the housekeeper, Masami Fujishiro. That was the topic at our family meeting last night."

"Oh-ho, marrying the housekeeper — and did all of you approve of this marriage talk?"

"How could we approve?" Keiichi said, raising his voice in irritation. "That housekeeper, she was only leading Father on. Just think about it. Can you really believe there was actual love between my sixty-year-old father and a woman in her thirties like 
Masami Fujishiro? It's just that he was infatuated with her youth. She was just leading him around by the nose and trying to break up our family."

"She was angling to get at his money?"

"What else? I can't imagine it was anything else. So I may have said some pretty harsh things last night. 'Wake up,' I said, 'You're being played,' those kinds of things.'

As he spoke, Keiichi pulled a crumpled pack of cigarettes from his shirt pocket.

He stuck one in his mouth, and went to light it with a cheap green lighter. But the lighter seemed to be empty, and just kept clicking without lighting.

“Oh dear, it's out of gas,” Harue whispered next to him, expression blank.

Keiichi clicked his tongue in annoyance and put the lighter back in his pocket, then held the cigarette out to Shuuji in the corner. "You've got a Zippo, don't you? Gimme a light.”

“Jeez, you think with all the money you've got you could buy something better than a cheap-o lighter."

As he spoke, Shuuji pulled out a Zippo oil lighter. It was a limited edition, with a New York Yankees logo engraved on the side. After lighting Keiichi's cigarette, he seemed to think he might as well join in and lit a cigarette of his own.

Reiko walked around the room quietly opening the windows. It seemed the Wakabayashi household had a lot of smokers.

"So, once you all protested against his marriage to Ms. Fujishiro, how did Tatsuo react?" 
“He was extremely discouraged." Teruo closed his eyes, sending up clouds of smoke from his pipe. "His feet kind of dragged when he went back to his room. Honestly, it broke my heart. Ms. Fujishiro may have been after his money, but I think my brother, at least, loved her from the bottom of his heart."

"It can't be helped. We just told him what we thought was best for him," Keiichi said, while Harue nodded beside him.

"That's right. Despite what happened, we did the right thing."

"But we never thought it'd turn out like this, did we," Shuuji murmured, blowing out a puff of smoke. "Dad really went and did it this time."

It seemed the whole family was agreed that Tatsuo Wakabayashi's death had been a suicide. Nobody offered any disagreement. And while everyone looked distraught, it was clear that no one was grieving very deeply for the deceased.

"Speaking of which, Inspector," Teruo said, adding one last qualification to his testimony, "you saw the wine on the table at the crime scene, I believe. That was the wine from his sideboard. It wasn't a particularly famous brand, it was just that he liked the look of the bottle perhaps, and he never drank it, but set it on the shelf as a kind of decoration. He always said, 'I'm saving it for a special day.' Everyone here knew that. That's why, the moment we saw that bottle next to my brother's body this morning, we became convinced that it was suicide. The day he would take his own life - there really is no more special day than that."

Deciding that the family's conversation had come to a convenient pause, Inspector Kazamatsuri gave a summary of the story so far. 
"So, as I understand it, this is what you all believe happened: last night, you all strongly opposed Tatsuo's marriage proposal; he returned to his room looking very depressed; then, having become completely discouraged, Tatsuo mixed poison into the wine he'd been saving, and drank it. In other words, suicide, plain and simple."

Everyone in the room nodded silently. Just as Reiko was thinking that maybe this should be seen as a suicide, she heard someone say, "No, it was not!"

The door flew open, revealing a slim woman in an apron. It was the housekeeper, Masami Fujishiro. She walked straight to Inspector Kazamatsuri with a troubled expression on her face.

“Mr. Wakabayashi ${ }^{61}$ did not commit suicide!" she protested.

At this unexpected outburst, Keiichi’s wife Harue responded angrily.

"What on earth are you saying! You have no right to butt in here! You're just the housekeeper - what do you know about him? Father committed suicide. And it was your fault!"

Harue's words were almost theatrical in their ferocity. Everyone else looked on anxiously. The scene in the living room that should have been something out of a crime drama had been rewritten into a romance-tragedy, featuring a furious emotional battle between the housekeeper and the eldest son's wife. All the while, Masami Fujishiro glared fiercely at Harue, without giving an inch.

“No, you're wrong. Mr. Wakabayashi was murdered!” she declared, dropping another bombshell.

${ }^{61}$ For “旦那椂” 
There was a startled murmuring from the men's camp.

“Shut your mouth! Do you even know what you're saying? Wait, I understand now. Since you can't marry him and get his money anymore, you've become desperate. I can't believe you, you horrible woman! You're just a little tramp trying to steal the Wakabayashi fortune! Even though you're just a stray from nowhere-shameless!"

Harue had abused the housekeeper with all sorts of nasty names, but worse than a tramp, a stray, a hussy, was the last shot—with everyone watching her expectantly, Harue delivered her ultimate insult.

"Who do you think has been keeping a roof over your head all this time, you ungrateful sow!"

At that, an entirely different kind of muttering started up among the group of men.

“Well now," Inspector Kazamatsuri said, glancing at the Rolex on his left wrist, "look at the time." He showed Reiko the watch face. The hands were pointing at 1:58pm. Maybe he was telling her it was about time for the midday soap opera to wrap up. She wanted to watch a little more, but oh well.

There was nothing for Reiko to do but take the Inspector's hint. "Well, why don't you two calm down," she said, stepping between the two glaring women. Reiko was disappointed: right now she was acting like one of the boring side characters from one of those noon soaps.

Once the uproar had calmed a bit, Inspector Kazamatsuri turned to the housekeeper again. 
"Now, Ms. Fujishiro, you're saying Tatsuo was murdered, but what makes you think so? Do you have a reason?"

"I do. Please look at this." Fujishiro took out her cell phone, opened it, and showed them the screen. "With all the fuss this morning, I didn't have time to check my messages. But when I finally did, just a little while ago, I saw that Mr. Wakabayashi sent me this last night."

Reiko looked over the inspector's shoulder at the cell phone screen. The sender was Tatsuo Wakabayashi, and the time of delivery was 12:50am. The estimated time of death was around 1:00am, so this mail must have been sent just before Tatsuo died. The message was very short. Inspector Kazamatsuri read it aloud.

““Thanks for the treat. I appreciate it. We'll talk more tomorrow.'- tomorrow??”

Of course. Naturally, this wasn't the kind of message you'd expect to see from someone who was planning to commit suicide. Reiko turned excitedly to the Inspector. “When he said 'we'll talk more tomorrow,' he probably meant 'we'll talk more about what happened at the family meeting tomorrow,' right? In other words, Tatsuo wasn't planning to kill himself."

“It certainly seems that way. If so, what was this 'treat'?" Inspector Kazamatsuri looked up from the cell phone screen and back at Masami Fujishiro. "Did you leave him some kind of treat last night?"

'No, I didn’t leave Mr. Wakabayashi anything. Maybe someone left something for him and put my name on it. And then I guess he sent off this thank-you message to me." 
"I see. But what could it have been..."

While Inspector Kazamatsuri was lost in thought, next to him, Reiko suddenly gasped loudly and snapped her fingers.

"The wine, Inspector! Someone left the wine for Tatsuo. Thinking it was left for him by Ms. Fujishiro, he drank it gladly. And that's how he died."

“That's it, poisoned wine! And so, Tatsuo Wakabayashi's death was not suicide, but homicide."

Reiko pushed her fake glasses up by the bridge with her index finger, and looked around the living room: the victim's brother, Teruo; his eldest son, Keiichi, and his wife Harue; the youngest son, Shuuji. One of these four, pretending to be Masami Fujishiro, had delivered the poisoned wine right to Tatsuo Wakabayashi's door.

\section{3}

"Wait just a second, Inspector," Shuuji barked nervously, as if he were trying to avoid having suspicion fall on him. "You're saying someone pretending to be the housekeeper left the wine-but how could they? What, they dressed up like her or something?"

Inspector Kazamatsuri had an uncharacteristically calm and matter-of-fact answer to this question.

"No, they didn't hand the wine over to him directly. And for that very reason, Tatsuo sent the thank-you message afterwards. Perhaps the treat was left while he was in the bath or something like that. It was likely done stealthily, while the room was unoccupied. If they had prepared a tray with the bottle of wine, a glass, as well as a note 
done in Ms. Fujishiro's handwriting, there can be no mistake that Tatsuo would see it as a treat left by his housekeeper. The perpetrator snuck these items into Tatsuo's room, set them on the table, and retreated. Afterwards, all he had to do was wait for Tatsuo to come back and drink the wine."

"But in that case, after he died, there would've still been poisoned wine on the tray. That, and a forged note."

"Perhaps, after the perpetrator killed Tatsuo, they came back again in the night and removed the bottle and the note. And then, yeah, the wine on the sideboard, they opened that. Then, let's say they drank a glass themselves, or something, to reduce the amount inside, and left it on the tray. That's totally possible, right?"

"No, I don't see how that's possible at all." This came from Teruo, pipe clenched in his teeth as he introduced a new problem in the case. "Inspector, you've been saying 'poisoned wine this' and 'poisoned wine that', but, you know, that's not exactly something they sell at the store. To leave poisoned wine as a treat, you'd have to put the poison in the wine bottle yourself. But, in order to put in the poison, you'd have to pull the cork. And to pull the cork, you'd have to peel the seal from the mouth of the bottle. So the killer just blithely left an open bottle? And my brother didn't think anything was strange about it and gladly drank it? No, I can't believe that. If it were me, as soon as I saw that the seal was missing, I'd be suspicious that someone had meddled with the bottle. Don't you agree, Inspector?" 
“Ah, of course, it's tricky to mess with a wine bottle, isn't it. Alright then, I've got it! The killer used a decanter! They put the poisoned wine in a decanter and then left it out for Tatsuo. It would be easy, and wouldn't seem suspicious."

However, Inspector Kazamatsuri’s idea was quickly crushed under Harue’s testimony.

"We have no decanter in our kitchen. If it had been left in a decanter, that by itself would have made Father suspicious."

"Well, if a decanter's no good, then a glass! The poison wasn't in the bottle, or a decanter, it was actually smeared on the inside of the glass. That must be it, right?"

"No, it can't be that." This time the one bursting the Inspector's bubble was Keiichi. "Father was kind of a neat-freak. Anything that touched his food-wine glasses included - had to be sparkling or he couldn't let it be. If the killer had smudged poison on the wine glasses, it probably would have been cloudy looking. And Father was so OCD, he definitely would have noticed something."

As each of his speculations was shot down, Inspector Kazamatsuri's pout grew deeper, and he fell silent. Looks like killing someone with poisoned wine really is easier said than done.

"I guess it really was suicide," Shuuji said, coming back to the suicide theory at last. "Dad decided to kill himself. But he thought just dying quietly would be no fun, so he sent that message to the housekeeper to make it seem like he wasn't thinking about killing himself. And if he did, his death would be seen as a murder, with us - his 
family_as the suspects. That was his plan. So, this is just Dad's little revenge on the rest of us, isn't it?"

At Shuuji's words, Teruo, Keiichi, and Harue nodded deeply in unison. The only person shaking her head "no" was Masami Fujishiro.

Eventually the questioning in the living room wrapped up without any real definite conclusion. Was Tatsuo's death suicide or homicide? Though the state of the crime scene made it look like suicide, the message on Masami Fujishiro's phone made it seem like homicide. But if it had been homicide, someone must have gone to great pains finding a way make him drink the poisoned wine.

However, Inspector Kazamatsuri's face was growing red, now that he had convinced himself it was murder. "The murderer is someone in that family! Those jerks, ganging up on me and shooting down all my deductions. I won't let them get away with it. I'll find a way to put at least one of them behind bars!"

I wish someone would put you behind bars, Reiko thought quietly to herself. And before you arrest someone on false charges. "Why don't we think calmly, Inspector."

"I am calm! That whole family is fishy. Too fishy. You think so too, don't you?"

“Well, yes, I suppose I do. With Tatsuo’s death, Teruo will be managing the veterinary clinic, and the inheritance will be split up mostly between Keiichi and Shuuji. So Keiichi's wife, Harue also stands to gain something. If you think about it, they all have a motive. I think there's a lot to be said for the murder theory."

“Oh, Hōshō!" Inspector Kazamatsuri gazed at Reiko with eyes full of emotion and gratitude. "You really are my one true ally!" 
What a bizarre thing to say, Reiko thought. Who would want to be your ally? she wanted to say, but her true thoughts were too blunt, so she just smiled vaguely and put conversation back on track. "The question is: who made Wakabayashi drink the poison wine, and how."

But, that was something she still didn't understand. Reiko gave herself some time to think by taking off her glasses and polishing the dark frames with her handkerchief, and let her mind wander. But no light bulbs went off. Apparently just wearing glasses doesn't suddenly increase your detective skill. And besides, it just seemed like they didn't have enough leads.

"Inspector Kazamatsuri!" Just then, an officer walked over to the Inspector, and gave a bow. "Actually, there's a witness with an important testimony, but...well...he's a ten-year-old boy."

A few minutes later, Reiko and Inspector Kazamatsuri visited the room of their ten-year-old witness, Yuuta Wakabayashi, Keiichi and Harue's only son. He would have been Tatsuo's grandson. But, since he was still just a child, it was hard to think of him as a key witness in the case. What kind of important testimony could this boy have? Inspector Kazamatsuri crouched down and sidled up to the boy with an awkward smile. "You're Yuuta, right? You said you had something to tell us — what might that be?"

"Um, well, um," Yuuta began, sounding overexcited. "I saw it-I did-last night — in the bathroom - there was a light — from grandpa's room-I could see it.” 
"I see, last night the bathroom light looked like one from grandpa's room, huh." Then Inspector Kazamatsuri clutched his head and groaned like a confused bear. "It's too strange...I can't even picture it."

“Inspector, I don't think that's what he was saying." Reiko shoved the Inspector to the side, and put the boy's words together again. "I've got it. Yuuta, last night when you went to the bathroom, you could see a light from your grandfather's room, right?"

"Yeah, that's right." The boy nodded happily.

"And what time was that, do you think?"

"The middle of the night. Around 2am." The boy held up two fingers when he answered. "Right around then, some lightning hit and there was a blackout here. Did you know about it, detective lady?"

"Wh-yes, of course I knew about it," Reiko said, though she hadn't actually found out about it until she woke up that morning... "How did you know there was a blackout, Yuuta? Weren't you sleeping?"

"I was, but the lightning woke me up. And then I suddenly had to go to the bathroom, and I was scared, but I went to the bathroom anyway. I took my flashlight over there, "cause the hallway was pitch-black, too."

Then the boy pointed at his door, at the place just beside the knob. A flashlight hung from a hook there. For that matter, in Tatsuo's room, too, there had been a flashlight in the same place. It seemed that the place for flashlights in the Wakabayashi household was next to the doorknob. 
"And then, when I was on the way to the bathroom, I looked outside from the window in the hall. From there, you can see grandpa's room on the other side of the garden, and I could see a light."

"What, the electricity was on in your grandfather's room?"

"Of course it wasn't, I told you: there was a blackout. It was a smaller light."

“Oh, I see.” Somehow, Reiko was feeling a kind of Are you stupid, lady? nuance in the boy's words, but she didn't let her anger show on her face, and asked another question. "Then someone had a flashlight in your grandfather's room?"

“Nah, it wasn't light from a flashlight. I think it was probably fire. It looked small, and orange, and it kinda flickered behind the curtain."

"Fire, you say??" Though he had been listening quietly all this time, Inspector Kazamatsuri finally ran out of patience and jumped into the conversation. "Hey kidyou're sure that's what it was?"

"Definitely, that's what I saw. I mean, I saw it two times. Once when I went to the bathroom, and then I saw it again on the way back."

Reiko thought the specifics of the boy's story were very likely authentic. And if his testimony were true, that would mean that Tatsuo Wakabayashi's death was a homicide. Because if someone had been in Tatsuo's room with some kind of flame at 2am, it couldn't have been Tatsuo himself. He would have died around 1am. So, the person with the flame who was in his room at that time would have to be his killer. “Look, Hōshō! My deductions were right after all." A crafty look came to Inspector Kazamatsuri's face and he turned it on Reiko. "The killer did go back to the 
scene of the crime. To take the wine bottle and the note. What this boy saw must have been the light the killer was carrying!"

With that decided, Inspector Kazamatsuri got in Yuuta's face again.

"Alright, kid, just tell me one more thing. Was the light you saw from a lighter, do you think? Or from a match? Or maybe a candle?"

"What, there's no way I'd be able to tell just from seeing it so far away. Are you stupid, mister?"

At the boy's blunt words, Inspector Kazamatsuri's eyebrows rose and he lost his cool. "Hey, punk!” he shouted. "That's 'sir' to you!"

That's what you're angry about?? Reiko sighed, and apologized to the boy in her mind.

Sorry, Yuuta. Like you said, he is pretty stupid.

"The 1995 Chateau Suduiraut Bordeaux."

Kageyama displayed the label of the expensive white wine to Reiko where she was reclining on the sofa. At a small nod from his mistress, he took up a sommelier knife and skillfully removed the seal, then the cork. He then poured the clear liquid into a beautifully polished wine glass. There was not a single wasted gesture in Kageyama's movements.

They were in the living room of the Hōshō mansion, with a view of the city skyline. Reiko's outfit, a feminine knit dress, was a sharp contrast to the pantsuit she wore for work. Her hair had been let down from its ponytail, and the black-framed 
fashion glasses had, of course, been removed. Now, she was no longer a female detective, but the one and only heiress of the Hōshō estate. Reiko raised her glass with a selfpossessed air, but paused just before it reached her lips.

"Could you have served me poison...?"

"What are you saying, Miss Reiko," Kageyama said, in a low emotionless voice. "Even if you were to serve poison to me, I would never do such a thing to you, Miss Reiko. You may put such fears to rest."

"I certainly cannot, when you say things like that!" In fact, the way he said it made it sound like, deep down, he had it out for her. This man might even hate me, Reiko thought, not for the first time.

"Then, let us look at things a touch more logically. With your own eyes you saw me bring out the brand-new wine bottle, with your own eyes saw me remove the cork. Again with your own eyes, saw me pour the wine into the glass - a glass polished until not a speck of cloudiness remained. Where might I have had a chance to poison the wine? Unless there was some black magic afoot, it is impossible that it is poisoned."

“Yes, that's certainly true." But Reiko's thoughts were far away from the moment at hand, and now had wandered back to the afternoon's case. "But the killer did succeed in making Tatsuo Wakabayashi drink poisoned wine-I wonder if it was black magic."

At Reiko’s whispered words, Kageyama’s eyes flashed behind his glasses. A faint smile suddenly crept onto his normally expressionless face. This man, Kageyama, who could say with a straight face that he had wanted to be either a pro baseball player or a private detective rather than a butler, was a strange one. 
"Somehow, Miss Reiko, it appears you are fortunately — that is, unfortunatelytroubled by a difficult case. If so, perhaps you could try talking about it with your old butler. You may make a new discovery."

"No way." Reiko turned away haughtily. "You're just waiting for another chance to call me an idiot. Well, no thanks. If I'm gonna get called an idiot by my own butler, I'd rather the case stay unsolved."

“Now, now, there's no need to say anything so extreme. I am wholeheartedly devoted to aiding you in every way, Miss Reiko.”

As Reiko watched Kageyama lower his head respectfully, she shook her own and sighed, bringing the glass to her mouth. A mellow taste, like nectar, filled her mouth. There was no poison. It was certainly a superior wine. As Reiko set her glass on the table, she finally made up her mind.

"Fine. I'll tell you, but just this time." In the end, as a detective she couldn't let the crime go unsolved, plus, Kageyama's deductive power wasn't something any idiot possessed. At least, Reiko admitted to herself, he might solve the riddle of the poisoned wine for me, if nothing else. "The victim was the head of the Wakabayashi Veterinary Clinic, Tatsuo Wakabayashi, sixty-two. He was discovered in his room, dead from poisoning, by the housekeeper..."

Kageyama stood humbly at Reiko's side, listening quietly and attentively. And, once Reiko had come to a stopping point, he said, "Yes, I see," and proceeded to lay out the facts for himself. 
"Put simply, this is the story: Tatsuo Wakabayashi drank the wine left for him as a late-night snack, and died. The poison was either mixed into the wine in the bottle, or coated on the inside of the glass - but which was it? However, in order to mix the poison into the wine in the bottle, one would have to remove the seal and the cork. Thus, this method would be all the more impossible in that it would have aroused Tatsuo's suspicions. On the other hand, with Tatsuo's fastidiousness, it is difficult to imagine the inside of the glass was coated with poison."

"Yes, yes, that's right. Could there be another clever way around it?" "No, I'm afraid nothing comes to mind," Kageyama replied immediately. "We must assume that Wakabayashi Tatsuo was made to drink the poison in one of the two ways just presented. And so: which way was it? I think the likelihood of the poison being on the inside of the wine glass is extremely low."

"Because of Wakabayashi's OCD?"

"There is that, yes, as well as one more important point: the killer purposefully chose wine as the refreshment they would leave. If the killer had been planning to put the poison on the inside of the glass, surely they would not have chosen wine. The reason being: of all the vessels available, there is none whose transparency is as important as that of a wine glass. For example, while someone may not particularly mind the discoloration found on a large sake cup or the cloudiness of a beer mug, any blemish on a wine glass is easily noticed. In short: nothing would reveal the poison more quickly than a wine glass. Regardless, this killer did not choose sake or beer, but wine. In other words, this can only mean that our killer never intended to put the poison on the inside of the glass." 
Of course, what Kageyama was saying made sense.

"So then, you think the killer tampered with the bottle, right? But tampering with the wine bottle is probably even harder than tampering with the glass, isn't it?"

"Perhaps, for that reason, it was the killer's target. The more one considers how unlikely it is that the killer tampered with the bottle, the more difficult it becomes to see how the killer could have done so."

“That is true, but...But how could they tamper with it? They can't have taken out the cork, added the poison, and then put the cork back in. As soon as they took off the seal it would leave signs that it had been tampered with."

"Quite so. They could not have removed the cork, or the seal."

"Then the bottle still would have been airtight."

"Incorrect, Miss Reiko. I do not mean to contradict, but it can be said that a wine bottle is both airtight and not. In this way, it is something of a half-hearted container."

“Airtight, but not..." Reiko cocked her head, puzzled. It really bugged her when Kageyama said completely nonsensical things like this. "Explain yourself."

"In the case of a wine bottle, the bottle itself is of course made of glass, which is a very airtight material. However, to seal it, simple cork is used. Because of the cork, while the wine is sealed, it can also be in contact with the outside air, allowing the wine to age - just like this 1995 Bordeaux. In short, as the cork can be easily removed with a simple corkscrew, it is a very elastic material and certainly not made to be highly airtight. Well, Miss Reiko? Can you see where there may be a chance for tampering here?" 
"Wait, wait, just wait a second," Reiko demanded, feeling sure there was a catch somewhere in Kageyama's words. "Bring me a new bottle of wine, one with the cork still in."

"Understood." Kageyama gave a bow and left, then returned a few minutes later carrying a bottle with a label Reiko didn’t recognize. "Will this suit, Miss Reiko?"

"Is this another Bordeaux?"

"No, Miss Reiko, this is a $¥ 1,995$ bottle from the Ito Yokado superstore."

"Oh, it really is - the price tag's still on it." Well, for this, Bordeaux or Yokado or whatever, anything would do. "Lemme see it."

Reiko took the bottle in hand and gazed at the cork from directly above. It was just as she thought. After just one glance, Reiko had finished her inspection.

"Look at this, Kageyama." Reiko turned the neck of the bottle towards her butler. "See, over the top of the cork, there's a metal cap about the size of a small coin and the seal is covering the edges. So the cork can't be removed. With this kind of setup, the killer couldn't even have touched the cork. There is no room for tampering."

How's that? Reiko thought, already celebrating her victory. She made a show of picking up her glass calmly from the tabletop and bringing it to her mouth. But Kageyama did not look disturbed in the least and, looking at Reiko pityingly from behind his glasses, prefaced his next statement with, "My sincerest apologies," then asked: "Is it possible, Miss Reiko, that you are blind?"

Unthinking, Reiko clenched her hand around her wine glass. It shattered with a dry crunch. White wine trickled from between Reiko's fisted fingers. Kageyama offered 
a handkerchief, and Reiko took it silently, wiping her hands. Seemingly unable to stand the long silence, Kageyama offered a few words.

"Er-If I have upset you, Miss Reiko, I am extremely sor-”"

“If 'I'm sorry' fixed everything, we wouldn't need the police, would we!!" Reiko balled up the wet handkerchief and threw it at her butler. "Just who are you calling 'blind'! I shouldn't have to tell you, my eyesight has always been the one good thing about me!"

“Just so, Miss Reiko. Calling you 'blind' was indeed an overstatement.” Kageyama had calmly caught the handkerchief Reiko had thrown at his face. "However, it cannot be denied that your powers of observation are lacking."

Then, Kageyama picked up the bottle once again in his left hand and held the mouth in front of Reiko's face.

"Look very closely, Miss Reiko. Certainly, the cork is not fully exposed. The top of the cork, as Miss Reiko indicated, is covered by a small metal cap. However, if you were to look very, very closely, perhaps you would notice two small holes about the size of pin pricks."

"What?!" At this unexpected revelation, Reiko stared down hard at the top of the bottle. Looking at it again, she saw that there really were two small holes in the metal cap. And through those holes, she could see the surface of the cork. "Oh, it's true-was it always like this?" 
"Indeed, Miss Reiko. Mostly likely they are air holes, to allow the wine to age properly. You will find holes such as these in the caps of most retailed wine. Have you never noticed?"

"Well, how could I, blind as I am?" Reiko replied with as much sarcasm as she could muster. "Anyway, what are you saying? These holes are so small, only a needle or something could get through."

"And so, we must assume the perpetrator passed a needle through one of these holes. Certainly, it was no ordinary needle. It was an injection needle. There was likely one of just the right size in the veterinary clinic-you understand now, Miss Reiko, how the killer did it?"

“Oh, of course!” Reiko snapped her fingers. "The killer injected the poison into the wine, right?"

There were those holes in the cork, plus the material of the cork was elastic enough to allow a needle to pass through. Utilizing those properties of the cork, the killer dissolved the cyanide in water and injected it into the bottle with an injection needle. That way, they wouldn't have to remove the seal, or the cork itself, leaving the bottle looking brand new and contaminating only what was inside. And so the killer took the successfully poisoned wine, disguised it as a midnight snack from Masami Fujishiro, and left it in Tatsuo Wakabayashi's room. There was no doubt that, after only a glance, Tatsuo would not have found any outward differences from any other wine bottle or suspected it to be poisoned wine. So Tatsuo had sent the thank-you message to Fujishiro 
and removed the cork himself. The mark left on the cork by the needle would have been so small that it was not impossible that Tatsuo could have missed it.

"What an awful thing to think up." With the trick revealed, Reiko felt a shiver pass through her body again. "Even so, who could have done such a thing..."

At Reiko's whispered words, Kageyama turned to her with a surprised expression.

"Oh dear, Miss Reiko, have you not yet realized who the killer is? I presumed you would have worked it out by now."

“How could I?" It was all because they couldn't figure out the identity of the killer that the police were working so hard, and Reiko was just barely putting up with these outbursts from the butler. "What, are you saying you know who did it??"

"Correct. It is not at all a difficult problem. It can be solved with simple reasoning."

With that, Kageyama's story came around to the reveal of the perpetrator. "Young Yuuta Wakabayashi's testimony is of utmost importance. The boy testified that he saw a wavering, orange light in the victim's room around $2 \mathrm{am}$. In other words, this means someone was in the victim's room at that time. There is no question that this was none other than the killer. Then, to what purpose was the killer visiting the victim's room in the middle of the night? Of course they were likely confirming that Tatsuo was dead, and to collect the key ingredient of the murder, the poisoned wine. This much, I trust, is clear?"

"Yes. Even Inspector Kazamatsuri thought as much." 
"The problem is here: we have the killer disposing of the evidence by the light of a flame. Why might the killer do such a thing?"

"Well, because of the blackout. The power was out, so the killer used a flame." "However, there was a flashlight at the scene. Hanging on a hook just by the door. And anyone in the Wakabayashi household would have know that there would be a flashlight there. Regardless, this killer used a flame, not the flashlight, to carry out his business. In other words, the killer chose not to use a flashlight even though he knew he could. Or, to think of it another way, perhaps it could be that the killer was not particularly troubled even without using the flashlight."

"I see. So you're saying the killer had something at hand that he was more accustomed to using, so for the killer, that was plenty. In short, the killer was a smoker and carried matches or a lighter. That's what you mean, right?"

“Just so, Miss Reiko. However, I cannot believe that a match would have been sufficient to carry out this work. The killer would have had to light match after match as he worked."

"I agree. So, it wasn't Teruo, since he usually prefers matches. If he were the killer, he would have gone straight for the flashlight."

"Indeed. The same is true for Keiichi's wife, Harue. Since she is not a smoker." “How do you know Harue isn't a smoker? No, she didn't smoke in front of us, but you can't just decide from that that she doesn't smoke at all."

"No, but recall, Miss Reiko, the moment when the gas ran out in Keiichi's cheap lighter. Keiichi did not ask Harue for a light, but his brother, Shuuji. If Harue smoked, 
surely Keiichi would have first asked for a light from his wife, who was sitting right beside him. Seeing as he did not, we can assume that Harue is not, after all, a smoker."

"I see." It was amazing how much he could see just from hearing someone else tell the story. "Well, that just leaves two. The brothers, Keiichi and Shuuji."

The both had plenty of motive with the inheritance, and they both carried lighters. Sure enough, one of the brothers was the culprit.

"Shuuji is the killer," Kageyama said, giving his conclusion with surprising ease.

"Wait just a second. Don’t tell me you're about to say 'because Keiichi’s lighter was out of gas' or something. Just because he was out of gas this afternoon, he might have had plenty left last night. Or Keiichi could even be the killer-his lighter ran out of gas because he used it all up at the crime scene last night — shouldn't we think about that?"

"No, I cannot imagine that Keiichi removed all the evidence in the middle of the night while carrying a lighter in one hand. Think carefully, Miss Reiko. The killer visited the crime scene last night at $2 \mathrm{am}$ and disposed of the poisoned wine. If he had only been disposing of the wine, there would be a possibility that he did so while holding a lighter. However, afterwards, the killer took the unopened wine from the sideboard, removed the cork, and set it on the table. Herein lies the problem. While this may be possible for the rest, I believe it is impossible to remove the cork from a wine bottle one-handed. Would one think to attempt such work with a lighter in one hand? Even though there is a handy flashlight nearby? I cannot believe it."

"Oh—well, if you put it that way." 
Certainly, if one were popping a wine cork in pitch darkness, leaving the flashlight on and doing it with both hands would be endlessly easier than doing it while holding a lighter. Reiko knew that much without even having to try it.

"But you can say the same thing about Shuuji, can't you? It'd be just as impossible for Shuuji to remove the cork with a lighter in one hand."

"However, in Shuuji's case, it is not so impossible. That is because his lighter is a Zippo oil lighter."

"What does it matter if it's a Zippo oil lighter or a cheapo Crown lighter-a lighter's a lighter, right? Aren't they the same thing?"

Kageyama shook his head sadly.

"It may well be that for you, Miss Reiko, who has never smoked, they would appear the same, but in fact, an inexpensive gas lighter and an oil lighter have an important difference. When one lights a dollar-store lighter, one must continue to hold down the switch to release the gas. Once the switch is released, the gas supply is cut off and the flame disappears. In short, a gas lighter is constructed in such a way that one cannot remove their hand for even a moment. On the other hand, with an oil lighter-_"

As he spoke, Kageyama pulled a package of cigarettes from his pocket and made a show of putting one in his mouth right in front of Reiko. Reiko sat dumbfounded, and Kageyama went even further, pulled out a well-loved Zippo oil lighter and, first lighting his cigarette, held the flame out to Reiko.

"In this way, with an oil lighter, because the wick is soaked in oil, once you light it, it will stay lit as long as you do not close the lid. And so..." Kageyama set the lighter 
down on the table. The lighter continued to burn, like a tiny candle. "As you can see, an oil lighter will not go out, even if one is not touching it. In this way, one might be able to remove the cork from a wine bottle with both hands. Therefore, the person who would not be troubled, even without using the flashlight, cannot be Keiichi with his gas lighter, but we must conclude that it was Shuuji, who carries an oil lighter."

His work done, Kageyama took a drag from his cigarette with a self-satisfied expression and asked, "What do you think, Miss Reiko?"

Hearing Kageyama's deduction, Reiko groaned in defeat, and could only watch as his cigarette smoke rose towards the ceiling. 


\section{$\underline{\text { References }}$}

Edogawa Ranpo. “The Caterpillar.” Trans. James B. Harris. Japanese Tales of Mystery \& Imagination. Tokyo, Japan: C.E. Tuttle Co, 1956. Print.

---. "D-zaka no satsujin jiken.” Edogawa Ranpo zenshū. eds. Hirohisa Shinpo, and Yuzuru Yamamae. Tokyo: Kōbunsha, 2003. Print.

---. “The Human Chair.” Trans. James B. Harris. Japanese Tales of Mystery \& Imagination. Tokyo: C.E. Tuttle Co, 1956. Print.

--- “The Red Chamber.” Trans. James B. Harris. Japanese Tales of Mystery \& Imagination. Tokyo: C.E. Tuttle Co, 1956. Print.

---. "Tantei shōsetsu wa taishū bungei ka." Hitori no bashō no mondai: nihon misuteri ronsh $\bar{u}$. eds. Hirohisa Shinpo, and Yuzuru Yamamae. Tokyo: Kawade Shobō Shinsha, 1995. Print.

---. "Twins." Trans. James B. Harris. Japanese Tales of Mystery \& Imagination. Tokyo: C.E. Tuttle Co, 1956. Print.

---. "The Two-Sen Copper Coin.” Trans. Jeffrey Angles. Modanizumu: Modernist Fiction from Japan, 1913-1938. Ed. William J. Tyler. Honolulu: University of Hawai'i Press, 2008. Print.

Edogawa Ranpo, Fuboku Kozakai, Yūsuke Hamada, Shōsaku Naka, and Shōichi Honda. Shifugo no yume: Edogawa Ranpo Kosakai Fuboku ofuku shokanshü. Iga City: Ranpo Kurabiraki Iinkai, 2004. Print.

Fowler, Edward. The Rhetoric of Confession: Shishösetsu in Early Twentieth-Century Japanese Fiction. Berkeley: University of California Press, 1988. Print.

Higashigawa Tokuya. Nazotoki wa dinaa no ato de. Tokyo: Kōbunsha, 2010. Print.

Kamei Hideo. Transformations of Sensibility: The Phenomenology of Meiji Literature. Ed. Michael K. Bourdaghs. Ann Arbor: Center for Japanese Studies, University of Michigan, 2002. Print.

Karatani Kōjin. Origins of Modern Japanese Literature. Trans. Brett de Bary. Durham: Duke University Press, 1993. Print.

Kawana, Sari. Murder Most Modern: Detective Fiction and Japanese Culture. Minneapolis: University of Minnesota Press, 2008. Print. 
"Kore kara hoso yotei no dorama." Fujitv. Fuji Television Network Inc., n.d., Web. 20 March 2012

Maeda Ai. Text and the City: Essays on Japanese Modernity. Ed. James A. Fujii. Durham: Duke University Press, 2004. Print.

"Nazotoki ga hyaku hachi jū ichi ten yon-manbu de rekidai sogo san-i ni ranku in." Yahoo. Yahoo Japan Corporation. 29 Dec. 2011. Web. 2 March 2012

Reichert, Jim. "Deviance and Social Darwinism in Edogawa Ranpo's Erotic-Grotesque Thriller 'Kotō No Oni',’ Journal of Japanese Studies. 27.1 (2001): 113-141. Print.

Seaman, Amanda C. Bodies of Evidence: Women, Society, and Detective Fiction in 1990s Japan. Honolulu: University of Hawai'i Press, 2004. Print.

Sengai Akiyuki. "Kaisetsu." Nazotoki wa dinaa no ato de. Higashigawa Tokuya. Tokyo: Kōbunsha, 2012. Print.

Silver, Mark. Purloined Letters: Cultural Borrowing and Japanese Crime Literature, 1868-1937. Honolulu: University of Hawai'i Press, 2008. Print.

Suzuki, Tomi. Narrating the Self: Fictions of Japanese Modernity. Stanford: Stanford University Press, 1996. Print.

Tsubouchi Shōyō. The Essence of the Novel. Trans. Nanette Twine. Brisbane:

Department of Japanese, University of Queensland, 1981. Print.

Tyler, William J. ed. Modanizumu: Modernist Fiction from Japan, 1913-1938. Honolulu: University of Hawai'i Press, 2008. Print.

Washburn, Dennis C. The Dilemma of the Modern in Japanese Fiction. New Haven: Yale University Press, 1995. Print.

Yamanouchi, Hisaaki. The Search for Authenticity in Modern Japanese Literature. Cambridge: Cambridge University Press, 1978. Print. 